\title{
Metaphysical and historical claims in the birth of tragedy
}

Book or Report Section

Published Version

Harloe, K. C. (2008) Metaphysical and historical claims in the birth of tragedy. In: Dries, M. (ed.) Nietzsche on time and history. A collection of essays. Walter de Gruyter, Berlin, pp. 271-285. ISBN 9783110190090 Available at http://centaur.reading.ac.uk/6933/

It is advisable to refer to the publisher's version if you intend to cite from the work. See Guidance on citing.

Publisher: Walter de Gruyter

All outputs in CentAUR are protected by Intellectual Property Rights law, including copyright law. Copyright and IPR is retained by the creators or other copyright holders. Terms and conditions for use of this material are defined in the End User Agreement. 


\section{CentAUR}

Central Archive at the University of Reading

Reading's research outputs online 
Nietzsche on Time and History

authors copy with permission by WdG 2008

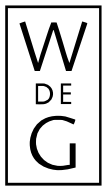


authors copy with permission by WdG 2008 


\title{
Nietzsche on Time and History
}

\author{
Edited by \\ Manuel Dries
}

authors copy with permission by WdG 2008

Walter de Gruyter · Berlin · New York 


\title{
authors copy with permission by WdG 2008
}

(0) Printed on acid-free paper which falls within the guidelines of the ANSI to ensure permanence and durability.

\author{
Library of Congress Cataloging-in-Publication Data
}

A CIP catalogue record for this book is available from the Library of Congress.

ISBN 978-3-11-019009-0

\section{Bibliographic information published by the Deutsche Nationalbibliothek}

The Deutsche Nationalbibliothek lists this publication in the Deutsche Nationalbibliografie; detailed bibliographic data are available in the Internet at http://dnb.d-nb.de.

(C) Copyright 2008 by Walter de Gruyter GmbH \& Co. KG, 10785 Berlin, Germany. All rights reserved, including those of translation into foreign languages. No part of this book may be reproduced or transmitted in any form or by any means, electronic or mechanical, including photocopy, recording, or any information storage or retrieval system, without permission in writing from the publisher.

Printed in Germany

Cover design: Martin Zech, Bremen.

Printing and binding: Hubert \& Co GmbH \& Co KG, Göttingen. 
If there is no goal in the whole of history of man's lot, then we must put one in: assuming, on the one hand, that we have need of a goal, and on the other that we've come to see through the illusion of an immanent goal and purpose. And the reason we have need of goals is that we have need of a will-which is the spine of us. 'Will' as the compensation of lost 'belief', i.e., for the idea that there is a divine will, one which has plans for us.

Friedrich Nietzsche, Nachlaß Summer 1886-Spring 1887, KSA 12, 6[9]

We are still growing continually, our sense of time and place, etc., is still developing.

Friedrich Nietzsche, Nachlaß April-June 1885, KSA 11, 34[124]

authors copy with permission by WdG 2008

'Timeless' to be rejected. At a particular moment of a force, an absolute conditionality of the redistribution of all forces is given: it cannot stand still. 'Change' is part of the essence, and therefore so is temporality-which, however, just amounts to one more conceptual positing of the necessity of change.

Friedrich Nietzsche, Nachlaß May-July 1885, KSA 11, 35[55] 
authors copy with permission by WdG 2008 


\section{Acknowledgements}

The essays in this volume were first presented at the $15^{\text {th }}$ International Conference of the Friedrich Nietzsche Society of Great Britain and Ireland, held at Peterhouse, Cambridge, in September 2005. I wish to take this opportunity to thank delegates and all those who participated in this event for the debates and critical discussions that shaped the research presented here.

I would further like to thank the Faculty of Philosophy and the Department of German at Cambridge for providing generous financial support. I am much indebted to Raymond Geuss, Simon Blackburn, Margaret Clare Ryan, and the Executive Committee of the Friedrich Nietzsche Society for their advice during the various stages of the editing of this volume.

Two of the contributions in this book are either drawn from or have appeared in full elsewhere, and this material appears with permission and my thanks. Raymond Geuss' article was previously published in his collection of essays Outside Ethics (Princeton: Princeton University Press, 2005). It is reprinted here with permission of Princeton University Press. Lawrence J. Hatab's article is drawn in parts from the text of his book Nietzsche's Life Sentence: Coming to Terms with Eternal Recurrence (New York: Routledge University Press, 2005). I thank Routledge for permission to publish the essay.

The four excerpts of printed music of Wagner, Bizet, and Stravinsky in Jonathan R. Cohen's essay appear here with permission of Dover Publishing, Chester Music Limited (Music Sales) and Schott Music GmbH \& Co. KG. Every effort has been made to trace and contact copyright holders. If there are any inadvertent omissions I apologize to those concerned and undertake to include suitable acknowledgements in future editions.

Finally, I would like to thank Walter de Gruyter Publishers for taking on this volume, Gertrud Grünkorn, Christoph Schirmer, and Jana Pokorny for their patient support, and Angela Blackburn for copyediting the final manuscript. 
authors copy with permission by WdG 2008 


\section{Contents}

Notes on Contributors $\quad$ XI

Abbreviations and Translations XIII

Nietzsche's Critique of Staticism

Introduction to Nietzsche on Time and History 1

Manuel Dries

\section{Part I: Time, History, Method}

Nietzsche's Cultural Criticism and his Historical Methodology 23

Andrea Orsucci

Thucydides, Nietzsche, and Williams

Raymond Geuss

The Late Nietzsche's Fundamental Critique

of Historical Scholarship

Thomas H. Brobjer

\section{Part II: Genealogy, Time, Becoming}

Nietzsche's Timely Genealogy: An Exercise in Anti-Reductionist

Naturalism

Tinneke Beeckman

From Kantian Temporality to Nietzschean Naturalism

R. Kevin Hill

Nietzsche's Problem of the Past

John Richardson

Towards Adualism: Becoming and Nihilism in Nietzsche's

Philosophy

Manuel Dries

\section{Part III: Eternal Recurrence, Meaning, Agency}

Shocking Time: Reading Eternal Recurrence Literally

Lawrence J. Hatab

Suicide, Meaning, and Redemption

Paul S. Loeb

Nietzsche and the Temporality of (Self-)Legislation 


\section{Part IV: Nietzsche's Contemporaries}

Geschichte or Historie? Nietzsche's Second Untimely Meditation in the Context of Nineteenth-Century Philological Studies Anthony K. Jensen

'An Uncanny Re-Awakening': Nietzsche's Renascence of the Renaissance out of the Spirit of Jacob Burckhardt Martin A. Ruehl

\section{Part V: Tragic and Musical Time}

Metaphysical and Historical Claims in The Birth of Tragedy 275 Katherine Harloe

Nietzsche's Musical Conception of Time

Jonathan R. Cohen 


\section{Notes on Contributors}

TINNEKE BEECKMAN is postdoctoral researcher for the Fund of Scientific Research, Flanders. She works for the Department of Philosophy, University of Brussels, Belgium.

ThOMAs H. BROBJER is Associate Professor in the Department of the History of Science and Ideas at Uppsala University, Sweden.

JONATHAN R. COHEN is Professor of Philosophy at the University of Maine in Farmington, USA.

MANUEL DRIES is Research Fellow at Wolfson College and the Faculty of Philosophy, University of Oxford, UK.

RAYMOND GEUSS is Professor of Philosophy at the University of Cambridge, UK.

KATHERINe C. HARloe is a Career Development Fellow in Classics at St. Anne's College,University/ of Oxford, UKK. by WdG 2008

LAWREnCE J. HATAB is Louis I. Jaffe Professor of Philosophy at Old Dominion University, Virginia, USA.

R. Kevin HILl is Associate Professor of Philosophy at Portland State University, USA.

Anthony K. Jensen is a Visiting Assistant Professor in the Department of Philosophy at Xavier University in Cincinnati, Ohio, USA.

PAUL S. LOEB is Professor of Philosophy at the University of Puget Sound, USA.

ANDREA ORSUCCI is Professor of Philosophy at the University of Cagliari, Italy.

JOHN RICHARDSON is Professor of Philosophy at New York University, USA.

MARTIN A. RUEHL is University Lecturer of German at Sidney Sussex College, University of Cambridge, UK.

HERMAN SIEMENS is University Lecturer in Philosophy at the University of Leiden, The Netherlands. 
authors copy with permission by WdG 2008 


\section{Abbreviations and Translations}

Friedrich Nietzsche's published and unpublished writings (Nachlaß) are quoted according to the following abbreviations:

A The Anti-Christ, cited by section number.

AOM 'Assorted Opinions and Maxims' (vol. 2, pt 1, of Human, All Too Human), cited by section number.

BAW Historisch-kritische Gesamtausgabe. Werke, ed. Hans Joachim Mette, 5 vols. (Munich: C. H. Beck, 1933-1940), cited by volume and page number.

BAB Historisch-kritische Gesamtausgabe. Briefe, ed. Hans Joachim Mette, 4 vols. (Munich: C. H. Beck, 1933-1940), cited by volume and page number.

BGE Beyond Good and Evil, icited byrsection numbers 2008

BT The Birth of Tragedy, cited by section number and KSA page number.

CV 'Five Prologues to Five Unwritten Books', cited by number and KSA page number.

CW The Case of Wagner, cited by section number.

D Daybreak, cited by section number.

EH Ecce Homo, cited by section heading and (when applicable) number.

EI 'On the Future of Our Educational Institutions', cited by section number.

GM On the Genealogy of Morality, cited by essay and section number.

GS The Gay Science, cited by section number.

HA Human, All Too Human, cited by volume and section number.

CV 'Five Prefaces to Five Unwritten Books', cited by preface number and KSA page number.

KGB Briefwechsel. Kritische Gesamtausgabe, ed. Giorgio Colli and Mazzino Montinari (Berlin: Walter de Gruyter, 1975-), cited by volume and page number.

KGW Werke. Kritische Gesamtausgabe, established by Giorgio Colli and Mazzino Montinari, ed. Wolfgang Müller-Lauter and Karl Pestalozzi (Berlin: Walter de Gruyter, 1967-), cited by volume, part, and page number. 
KSA Sämtliche Werke. Kritische Studienausgabe, ed. Giorgio Colli and Mazzino Montinari (Berlin: Walter de Gruyter, 1967-), cited by volume and page number. The Nachlaß is cited by date, KSA volume, notebook section, and fragment number.

KSB Sämtliche Briefe. Kritische Studienausgabe Briefe, ed. Giorgio Colli and Mazzino Montinari (Berlin: Walter de Gruyter, 1986-), cited by volume and page number.

NCW Nietzsche contra Wagner, cited by section heading.

OTL 'On Truth and Lying in a Non-Moral Sense', cited by KSA page number.

PTAG 'Philosophy in the Tragic Age of the Greeks', cited by section number.

TI Twilight of the Idols, cited by section heading and number.

UM Untimely Meditations, cited by part and section number, and (when applicable) KSA page number.

$\mathrm{Z} \quad$ Thus Spoke Zarathustra, cited by part, section heading, and (when applicable) number.

authors copy with permission by WdG 2008

Note on Translations of Nietzsche's Works

The contributors to this volume have used different translations of Nietzsche's texts, often modified by the individual contributor. At the end of each essay the reader will find a list of the translations used. Where no such list has been provided the contributor has relied exclusively on his or her own translations. All translations from Nietzsche's Nachlaß are usually by the individual contributors, although other translations have been consulted whenever possible, notably The Will to Power, trans. Walter Kaufmann and R. J. Hollingdale (New York: Random House, 1967), and Writings from the Late Notebooks, ed. Rüdiger Bittner, trans. Kate Sturge (Cambridge: Cambridge University Press, 2003). 


\section{Metaphysical and Historical Claims in The Birth of Tragedy}

\section{Katherine Harloe}

What is The Birth of Tragedy about? From a contemporary critical perspective, the very attempt to pose this question may appear hopelessly naive. Even if the furthest reaches of the complex and varied history of the reception of Nietzsche's first book are ignored, debates among scholars over its coherence, content, and significance within Nietzsche's thought have shown no signs of abating, and Montinari's comment twenty-five years ago that 'the entire problem of interpretation of Nietzsche's philosophical firstling is still wide open' appears equally apposite today (Montinari 1980, p. 5). In this essay I wish to question an assumption which I believe has come increasingly to guide interpretation of The Birth of Tragedy, and which is common to many who hold very different substantive views of its content. This is the idea that it should be read primarily as a contribution to what was, admittedly, one of the major debates of German philosophy after Kant: that of the possibility of metaphysics. If this assumption is granted, the most important question to ask about Nietzsche's first book becomes whether or not he there asserts or denies the possibility of 'transcendent' knowledge of the ultimate nature of the world. Regardless of the substantive differences between the answers scholars have given to this question over the past few decades, agreement that The Birth of Tragedy is essentially an exercise in metaphysics has informed many influential readings.

Sometimes the assumption is very much a background presence in a discussion which focuses on different themes. Consider, for example, Alexander Nehamas' views as put forward in his book Nietzsche: Life as Literature (Nehamas 1985). His interpretation of Nietzsche places the doctrine of perspectivism centre-stage and is primarily concerned with the writings of the 1880s rather than the 1870s. The Birth of Tragedy is, however, mentioned in order to support the following observation:

Nietzsche seems to have believed that there are some ultimate facts, some noninterpretive truths, concerning the real nature of the world ... he denied that these facts could ever be correctly stated through reason, language, and science. Yet he also believed (and here the influence of Schopenhauer became dominant) that tragedy, primarily through the musically inspired, 'Dionysian' chorus, can intimate the final truth that the ultimate nature of the world is to 
have no orderly structure: in itself the world is chaos, with no laws, no reason, and no purpose. (Nehamas 1985, pp. 42-43)

The Birth of Tragedy is here invoked as a document of Nietzsche's early faith in the possibility of metaphysics, and is thereby distinguished from the later writings, in which 'Nietzsche comes to deny the very contrast between things-in-themselves and appearance which was presupposed by his discussion of tragedy' (Nehamas 1985, p. 43). The assumption does rather more work in motivating the influential, deconstructive readings of The Birth of Tragedy offered by Paul de Man and Philippe LacoueLabarthe (de Man 1979, pp. 79-102; Lacoue-Labarthe 1971). As Henry Staten has convincingly shown, it is because de Man interprets The Birth of Tragedy as an attempt to depict an 'ontological hierarchy', according to which the Dionysian is genetically prior to the Apollonian, that his verdict on it as a text that is logocentric - and his consequent deconstruction-can operate (de Man 1979, pp. 83, 85; Staten 1990, pp. 187-216). More recently, James I. Porter has argued against the view that any metaphysical thesis is asserted in The Birth of Tragedy and in favour of reading it as an attempt 'to mimic and challenge - through a mixture of parody, irony, implausibility, and logical circularityenthe metaphysicat banalities that the work superficially conveys' (Porter 2000a, p. 87). While his reconstruction of the content of Nietzsche's argument could not be more opposed to that of Nehamas or de Man, his reinterpretation of Nietzsche as an antimetaphysician nevertheless leaves the question of metaphysics in the foreground.

This first interpretative question is usually thought to be bound up closely with a second contested issue: the Schopenhauerianism of Nietzsche's first book. The connection seems straightforward enough: The Birth of Tragedy's elaboration of the Apollonian-Dionysian polarity conspicuously deploys Schopenhauerian language, and Schopenhauer's magnum opus, The World as Will and Representation (Schopenhauer 1969 [English]; 1949a and b [German]) ${ }^{1}$, offers a systematic metaphysics in the traditional sense of a set of interconnected claims about the ultimate nature of the world. We might, therefore, take The Birth of Tragedy's Schopenhauerianism as an indicator of its metaphysical commitment: insofar as Nietzsche's position there may justly be characterized as Schopenhauerian, he is defending a metaphysical thesis. It is my contention that this apparently plausible inference is in fact mistaken, and rests upon an oversimplification of what 'Schopenhauer' could have represented for Nietzsche at the time of

Translations from Schopenhauer's and Nietzsche's Nachlaß and letters are my own. 
writing The Birth of Tragedy. Appreciating this leads us to recognize that The Birth of Tragedy may be 'Schopenhauerian' yet not 'metaphysical' in any straightforward sense.

My argument to this effect will proceed by means of a critique of one of the most recent attempts to give an overarching interpretation of The Birth of Tragedy: the aforementioned reading of Porter. Porter's discussion is important as it exposes of some of the puzzles and difficulties that arise when the interpretative question with which I began is answered in the affirmative. He is correct to insist that certain aspects of The Birth of Tragedy's 'narrative structure' - its language, imagery, and train of argumentcall into question the notion that its author is 'uncritically enthralled to a metaphysics that ... [he] later abandoned' (Porter 2000a, p. 20). In reinterpreting The Birth of Tragedy as an 'attack on metaphysics' (ibid., p. 28), however, and equating this with an attack on Schopenhauer, Porter repeats what I suggest are a mistaken interpretative assumption and attendant oversimplification. By responding to his arguments, then, I hope to be able to indicate why both ways of answering the question of metaphysics in relation to The Birth of Tragedy miss what is really at issue.

\section{authors copy with permission by WdG 2008}

It would, of course, be impossible to provide an adequate response to Porter in the course of this essay. This is not just because his reading of The Birth of Tragedy is based on an detailed and broad-ranging consideration of Nietzsche's notebooks and early philological writings, ${ }^{2}$ but also because he attributes to Nietzsche a deliberate strategy of what Quentin Skinner has termed 'oblique reference' (Skinner 1969, pp. 32-35). Put crudely, this is the writing of something one does not believe in order to disguise as well as to set out what one means to say. As Skinner points out, oblique strategies pose particular problems of interpretation, assessment of which requires close attention to the possible linguistic (textual) contexts of a particular work in order to decide whether its author is subverting or sustaining the ideas, generic conventions, topoi and so on, of his predecessors and contemporaries. Porter interprets The Birth of Tragedy as a subversive text; the immediate target of its critique is Wagnerian and Schopenhauerian metaphysics. My comments here are intended to draw attention to some aspects of the Schopenhauerian and Wagnerian linguistic

2 In addition to Porter 2000a, the focus of my discussion here, this reading is extended in Porter 2000b. 
context, overlooked by Porter, which I believe support a different interpretation.

One of the cornerstones of Porter's reading is his interpretation of the Dionysian as a 'pleat in the texture of appearance' (2000a, p. 49; see pp. 33-50, passim) and hence of metaphysics as something 'generated from within' appearance itself. Repeatedly in The Birth of Tragedy, Nietzsche seems to claim that the Dionysian is ontologically prior to the Apollonian-'the eternal and original artistic power that first calls the whole world of phenomena into existence' (BT 25, quoted in Porter 2000a, p. 36). This message is, however, undermined by passages such as the allusion to Lucretius in The Birth of Tragedy 1, which implies that all divinities, Dionysus included, are the product of dreams. Just as much as Apollo, then, who is explicitly associated with dreams and deception, the opening section of The Birth of Tragedy provides a hefty hint that Dionysus is illusory: an aspect of human psychology rather than a constituent of the deeper reality behind appearances. Nevertheless - and this is the flip-side of Porter's reading-Nietzsche tells us that such illusions cannot simply be done away with. They are the product of the deep-seated human need to project some higher meaning onto existence ${ }_{\text {vith }}$ permission by WdG 2008

These are noteworthy observations, but do they, as Porter thinks, amount to a decisive move away from a Schopenhauerian or Wagnerian position? Let us consider the crucial passage where Nietzsche states that 'As Lucretius envisages it, it was in dream that the magnificent figures of the gods first appeared before the souls of men' (BT 1, KSA 1, p. 26). The sentence continues by quoting Wagner:

In dream the great image-maker saw the delightfully proportioned bodies of superhuman beings; and the Hellenic poet, if asked about the secrets of poetic procreation, would likewise have reminded us of dream and would have given an account much like that given by Hans Sachs in the Meistersinger:

My friend, it is the poet's task

To mark his dreams, their meaning ask.

Trust me, the truest phantom man doth know

Hath meaning only dreams may show:

The arts of verse and poetry

Tell nought but dreaming's prophecy. (ibid.)

In the following paragraph, which continues the theme of dreaming, we are referred to Schopenhauer:

Philosophical natures even have a presentiment that hidden beneath the reality in which we live and have our being there also lies a second, quite different reality; in other words, this reality too is a semblance, and Schopenhauer actually states that the mark of a person's capacity for philosophy is the gift of 
feeling occasionally as if people and all things were mere phantoms or dreamimages. (ibid.)

Porter is, I think, correct to interpret these passages as implicating the Dionysian and the supposedly higher reality it symbolizes in 'appearances', but how are we to read the specific allusions to Wagner and Schopenhauer in this context?

The immediate Schopenhauerian allusion is to a passage from his Nachlaß, ${ }^{3}$ but the theme is treated at greater length in volume 2 of The World as Will and Representation, in a chapter tellingly titled 'On Man's Need for Metaphysics' (Schopenhauer 1969, vol. 2, pp. 160-187/1949b, pp. 175-209). There Schopenhauer talks of man as an animal metaphysicum, permanently afflicted by the desire for metaphysical knowledge. In the face of the evident suffering and misery of life, humans are compelled to wonder why the world exists. The desperate need for an answer to this question is, Schopenhauer says, the origin of all 'metaphysical' thought, both religious and philosophical:

Temples and churches, pagodas and mosques, in all countries and ages, in their splendour and spaciousness, testify to man's need for metaphysics, a need strong and ineradicable, which followss elose on/thecphysical. (1969, vol. 2, p. 162/1949b, p. 177)

The difference between religion and philosophy does not consist in the claim, common to both, to embody a truth beyond appearances, but rather in their mode of presentation. Religions provide a 'popular metaphysics' resting upon revelation, and can be true solely sensu allegorico. Philosophy, by contrast, appeals to thought and conviction and claims to be true sensu proprio (1969, vol. 2, pp. 166-168/1949b, pp. 183, 185). Nevertheless, both arise from humans' need, faced with the misery of life, to make 'metaphysical assumptions' about the existence of another world whose real character is separated by 'a deep gulf, a radical difference' from anything of which they can conceive (1969, vol. 2, p. 178/1949b, pp. 197, 198). Belief in metaphysical doctrines is, then, a human cognitive response to misery and helplessness in the face of existence, and both religion and philosophy, as forms of metaphysics, gain their content by a projection of the antithesis of the world of 'appearances' into an assumed beyond. In this

3 'He who does not feel occasionally as if people and all things were mere phantoms or dream-images has no gift for philosophy. For it arises out of the contrast of individual things with the Idea of which they are the appearance' (Schopenhauer 1864 , p. 295). An annotated copy of this work survives among Nietzsche's personal effects, although the date at which he purchased it is unknown (see Oehler 1942, p. 21). 
chapter of The World as Will and Representation, Schopenhauer presents a view of the origins of metaphysical thought which is surprisingly similar to Porter's interpretation of the hidden message of The Birth of Tragedy 1.

The heavily annotated copy of The World as Will and Representation which survives among Nietzsche's personal possessions is part of the Collected Works edited by Julius Frauenstädt and published in 1873-1874, after the appearance of The Birth of Tragedy (Oehler 1942, p. 21). While there can be no doubt that Nietzsche read The World as Will and Representation extensively in the years 1865-1872, it is impossible to prove which chapters he studied most attentively. It is, however, extremely likely that he was familiar with the chapter discussed above, as it contains Schopenhauer's problematic and much-commented-upon claim that, unlike the systems of his predecessors, his metaphysics is not transcendent:

And although no one can recognize the thing-in-itself through the veil of the forms of perception, on the other hand everyone carries this within himself, in fact he himself is it; hence in self-consciousness it must be in some way accessible to him, although still only conditionally. Thus the bridge on which metaphysics passes beyond experience is nothing but just that analysis of experience into phenomenon and thing-in-itself in which I have placed Kant's greatest merit. For it contains the proof of a kernel of the phenomenon different from the phenomenon itself. It is true that this kernel can never be entirely separated from the phenomenon, and be regarded by itself as an ens extramundanum; but it is known always only in its relations and references to the phenomenon itself. The interpretation and explanation of the phenomenon, however, in relation to its inner kernel can give us information about it which does not otherwise come into consciousness. Therefore in this sense metaphysics goes beyond the phenomenon, i.e., nature, to what is concealed in or behind it ( $\tau \dot{o} \mu \varepsilon \tau \dot{a} \tau \dot{o} \varphi v \sigma i x o ́ v)$, yet always regarding it only as that which appears in the phenomenon, not independently of all phenomenon. Metaphysics thus remains immanent, and does not become transcendent; for it never tears itself entirely from experience, but remains the mere interpretation and explanation thereof, as it never speaks of the thing-in-itself otherwise than in its relation to the phenomenon. This, at any rate, is the sense in which I have attempted to solve the problem of metaphysics, taking into general consideration the limits of human knowledge which have been demonstrated by Kant. (Schopenhauer 1969, vol. 2, pp. 182-183/1949b, pp. 203-204)

This claim was interrogated by Rudolf Haym in his 1864 essay on Schopenhauer, which Nietzsche read in $1866 .{ }^{4}$

4 Nietzsche to Hermann Mushacke, 27 April 1866, KGB I 2, pp. 126-129; Nietzsche to Carl von Gersdorff, end-August 1866, KGB I 2, pp. 156-161 (see Barbera 1994). 
The likely linguistic contexts of the appeal of The Birth of Tragedy 1 to Wagner complement this picture of congruence between Nietzsche's arguments and Schopenhauerian themes. The passage Nietzsche quotes centres around the paradoxical notion of the 'truest phantom' or 'illusion' (wahrster Wahn), and is taken from Act III of Die Meistersinger, in which Wahn is a prominent theme. ${ }^{5}$ It is therefore relevant to consider Wagner's letter to Ludwig II of Bavaria (Wagner 1911 [German]/1995 [English]), published in 1873 under the title Über Staat und Religion, which Nietzsche read in manuscript in $1869 .^{6}$ In this letter, Wagner combines a Schopenhauerian metaphysical standpoint with a lengthy analysis of political and religious ideas as forms of Wahn, necessary illusions:

Blindness is the world's true essence, and not Knowledge prompts its movements, but merely a headlong impulse, a blind impetus of unique weight and violence, which procures itself just so much light and knowledge as will suffice to still the pressing need experienced at the moment. So we recognize that nothing really happens but what has issued from this not far-seeing Will that answers merely to the momentarily-expressed need. (1995, p. 10/1911, p. 8)

Humans are the unwitting instruments of this blind striving for existence, and both patrigtismo(which induces them to place the ends of state above their own egoistic goals) and religion (which counsels resignation in the face of the wretchedness of existence) are ruses by which they are induced to serve the ends of Will. This outlook leads Wagner to give the following analysis of religious feeling:

Its inmost kernel is denial of the world-i.e., recognition of the world as a fleeting and dreamlike state reposing merely on illusion — and struggle for Redemption from it, prepared-for by renunciation, attained by Faith. In true Religion a complete reversal thus occurs of all the aspirations to which the State had owed its founding and its organising: what is seen to be unattainable here, the human mind desists from striving-for upon this path, to ensure its reaching by a path entirely opposite. To the religious eye the truth grows plain that there must be another world than this, because the inextinguishable bent-tohappiness cannot be stilled within this world, and hence requires another world for its redemption. What, now, is that other world? So far as the conceptual faculties of human Understanding reach, and in their practical application as intellectual Reason, it is quite impossible to gain a notion that shall not

5 I am thinking in particular of Hans Sachs' famous Wahn-monologue at the end of act III, scene 1 . The passage Nietzsche cites is from the beginning of act III, scene 2 .

6 See Barbera 1994, p. 219 (no. 4). As late as 1873, Nietzsche thought fit to praise this work of Wagner's as 'in the highest sense "edifying"' (Nietzsche to Gersdorff, 2 March 1873, KSB II 3, p. 131). 
clearly show itself as founded on this selfsame world of need and change: wherefore, since this world is the source of our unhappiness, that other world, of redemption from it, must be precisely as different from the mode of cognisance whereby we are to perceive that other world must be different from the mode which shews us nothing but this present world of suffering and illusion. (1995, pp. 23-24/1911, pp. 20-21, emphasis mine)

Religious feeling is awesome in nature-Wagner calls it 'wonder-working' (wunderwirkend) and 'sublime' (erhaben) (1995, p. 25/1911, p. 21), but is nonetheless illusion for all that. In explicitly associating religious thought with illusion and dream, Wagner goes further than Schopenhauer does in the passages I have quoted, but both the language and the content of this recognizably Schopenhauerian train of thought foreshadow those aspects of The Birth of Tragedy 1 that Porter emphasizes. ${ }^{7}$

If Porter's argument that the Dionysian or the metaphysical originates as the compensatory fantasy of needy and suffering human beings is granted, it seems nevertheless that the elaboration of these thoughts in the opening sections of The Birth of Tragedy draws considerably on Schopenhauer's treatment of the same theme. It is, moreover, not merely Nietzsche's account of the origins of metaphysics that is Schopenhauerian in tenor. His discussion of the resurgence of the need for metaphysics in his contemporary era is also redolent of Schopenhauer. According to Nietzsche, this need is provoked anew by the eventual bankruptcy of the optimistic, 'Socratic' belief that science can provide a fully satisfactory explanation of the world (see especially BT 15, 18). The second half of Schopenhauer's chapter 'On Man's Need for Metaphysics' is likewise devoted to an extensive and scathing discussion of the ambitions of science to explain the world:

Naturalism, or the purely physical way of considering things, will never be sufficient, it is like a sum in arithmetic that never comes out. Beginningless and endless causal series, inscrutable fundamental forces, endless space, beginningless time, infinite divisibility of matter, and all this further conditioned by a knowing brain, in which alone it exists just like a dream and without which it vanishes-all these things constitute the labyrinth in which naturalism leads us incessantly round and round ... In fact, even if a man wandered through all the planets of all the fixed stars, he would still not have made one step in metaphysics. On the contrary, the greatest advance in physics will only

7 The connection between metaphysical 'knowledge' and dreams is treated at length in Schopenhauer's essay on spirit-seeing (Schopenhauer 1960 [German]/1974 [English]). This discussion inspired Wagner's 1870 centenary essay on Beethoven, which Nietzsche praises in the Preface to BT and in section 16 (KSA 1, pp. 23, 104). 
make the need for a system of metaphysics felt more and more, since the corrected, extended, and more thorough knowledge of nature is the very knowledge that always undermines and finally overthrows the metaphysical assumptions that till then have prevailed. (Schopenhauer 1969, vol. 2, pp. $177-$ 178/1949b, pp. 196-197)

Like Nietzsche, Schopenhauer is disdainful of the ambitions of science, and believes that it will eventually refute itself, provoking a return to metaphysical speculation. Not only are there general thematic parallels, but the very terms in which Nietzsche expresses the cultural importance of Socratism echo the cosmic imagery of Schopenhauer's contemptuous dismissal. ${ }^{8}$

An element of continuity with Schopenhauerian ideas is also, I would argue, implied by the imagery of veiling that Nietzsche uses to depict the insight offered by the Dionysian state:

Now, hearing this gospel of universal harmony, each person feels himself to be not only united, reconciled or merged with his neighbour, but one with him, as if the veil of maya had been torn apart, so that mere shreds of it flutter before the mysterious primordial unity. (BT 1, KSA 1, pp. 29-30; see too BT 15, KSA 1, pp. 98-99; BT 24, KSA 1, p. 150)

Porter points out that the veracity of this vision is far from assured, suggesting that the subjunctive character of the 'as if'-clause and the continued fluttering of the tattered veil imply that the Dionysian vision does not provide immediate insight into the beyond (2000a, pp. 51-52). He concludes that this represents a critique of Schopenhauer; but again, there are Schopenhauerian precedents. We have already seen Schopenhauer speak of 'the veil of the forms of perception' in The World as Will and Representa-

8 'For the first time, thanks to this universality, a common network of thought was stretched over the whole globe, with prospects of encompassing even the laws of the entire solar system' (BT 15, KSA 1, p. 100). They also contain echoes of Wagner. Nietzsche characterizes the Socratic instinct for scientific knowledge as a 'sublime metaphysical illusion' (BT 15, KSA 1, p. 99) and comments that without its influence, human energy would have been 'applied instead to the practical, i.e., egotistical goals of individuals and nations'. The 'wars of extinction' that would have ensued would have led to a generalized and suicidal pessimism of the kind which, Nietzsche claims, 'has existed throughout the entire world, wherever art has not appeared in one form or other, especially as religion or science, to heal and to ward off the breath of that pestilence' (BT 15, KSA 1, pp. 100; see also p. 102). Wagner had likewise argued that patriotic or political Wahn is still too close to individual egoism to be stable, and will collapse into war unless supplemented by the illusions of faith (1995, pp. 15-19/1911, pp. 12-14). Nietzsche's account of the way science functions as a form of illusion is thereby aligned with Wagner's discussion of religion. 
tion II, chapter 17, when wrestling with the thorny issue of human beings' 'inner' experience of the thing-in-itself (1969, vol. 2, pp. 182-183, quoted above). He resorts to this metaphor again in the following chapter, this time to confess the impossibility of an unshrouded view:

Meanwhile it is to be carefully noted, and I have always kept it in mind, that even the inward observation we have of our own will still does not by any means furnish an exhaustive and adequate knowledge of the thing-in-itself ... in this inner knowledge, the thing-in-itself has indeed to a great extent cast off its veils, but still does not appear quite naked ... Accordingly we have to refer the whole world of phenomena to that one in which the thing-in-itself is manifested under the lightest of all veils, and still remains phenomenon only insofar as my intellect, the only thing capable of knowledge, still always remains distinguished from me as the one who wills, and does not cast off the knowledgeform of time even with inner perception. (Schopenhauer 1969, vol. 2, pp. 197, 198/1949b, pp. 220-221) ${ }^{9}$

These passages are taken from the second volume of The World as Will and Representation, which was added in the second edition of 1844 and forms a supplement to volume 1 . There is no question that such statements are hard to reconcile with the confidence with which the thesis that the world is Will is presented in the first edition of Schopenhauer's work. It is nevertheless evident that the terms of what Porter sees a radical critique of Schopenhauer are available from Schopenhauer himself.

I have, I hope, succeeded in showing that allusions to these particular chapters of The World as Will and Representation are prominent at several points in The Birth of Tragedy. Nietzsche's selective allusions may fairly be said to emphasize this self-critical moment in Schopenhauer, but do they thereby amount to a wholesale rejection of whatever he may have understood the elder philosopher to stand for? An alternative interpretation is suggested by yet another apologia for the use of metaphysical language - this time from Nietzsche's own notebooks. The passage is from an early draft of Fragment 10[1], which survives labelled by Nietzsche as

9 The imagery of the veil has a long pedigree in German philosophical aesthetics, evoked by Kant Goethe, Schiller, Novalis, Hegel, and others. See Gombrich 1985 for some examples. The implication is always double-edged: a veil conceals as much as it reveals. It is this tradition that Nietzsche taps into with his remarks about the veiling and unveiling in BT 15 and in The Gay Science (GS Preface to the second edition 4, KSA 3, pp. 351-352; GS 57, KSA 3, pp. 421-422). 
'Fragment of an extended form of "The Birth of Tragedy" written in the first weeks of the year 1871' (KSA 7, pp. 333ff.):

If I ventured in passing to speak of genius and of appearance as if a knowledge that exceeded every bound stood at my disposal and as if I were able to see out of the pure, great eye of the world, in what follows it will be explained that in using this figurative language [Bildersprache] I do not believe that I have stepped beyond anthropomorphic bounds. But who could endure existence without such mystical possibilities? (KSA 14, p. 541)

Porter states that Nietzsche's position in The Birth of Tragedy is 'not only that metaphysics is a fictional enterprise worthy of being shattered once and for all but also that its resurrection is an inescapable and constitutional need deeply implanted in human nature' (Porter 2000a, p. 9; emphasis mine). Although he recognizes that Nietzsche portrays metaphysical speculation as a matter of human need, his overall discussion of The Birth of Tragedy suggests that its argument is weighted heavily towards critique. In the passage above, however, we see Nietzsche underlining in poignant terms a conclusion that we have also seen Schopenhauer and Wagner emphasize: the need for a myth such as the metaphysical provides in order to endure existence.tNietzsche's acknowledgement $\mid$ of this need together with its Schopenhauerian precedent, raises the possibility that The Birth of Tragedy deploys Schopenhauer not in parodic fashion, as a weapon with which to shatter all such illusions, but rather as a means of developing them in a new and superior form. ${ }^{10}$

This interpretation also coheres with Nietzsche's comments about the work of Friedrich August Lange. Porter argues that it was reading Lange that caused Nietzsche to apostatize from Schopenhauer (Porter 2000a, pp. 5, 9-16). Yet, in the same August 1866 letter to Gersdorff in which he praises Lange's History of Materialism as 'splendid and highly instructive' (KGB I 2, p. 159), Nietzsche draws a different conclusion: 'You see that even in the face of this most exacting critique our Schopenhauer remains for us, indeed, he almost becomes us even more.' What Lange's arguments show is, according to Nietzsche, that philosophy can only be a form of art, of which none other than Schopenhauer furnishes the highest example:

If philosophy is art, then even Haym may hide from Schopenhauer; if philosophy should be edifying, then I at least know no philosopher who edifies more than our Schopenhauer. (KGB I 2, p. 160)

My suggestion is therefore that Nietzsche draws upon Schopenhauer in The Birth of Tragedy as part of his attempt to foster a new form of Wagnerian

10 Note the echo in Nietzsche's 1873 praise of Wagner's 'On State and Religion' as 'highly "edifying", quoted in n. 6 above. 
Wahn: an acknowledgement and indulgence of the need to find a higher meaning in existence, however illusory that meaning may be. This project may seem opposed to Schopenhauer's goal of presenting a system of metaphysics in the grand style, yet there are sufficient counter-currents in The World as Will and Representation to enable Nietzsche to enlist his predecessor in the service of this enterprise. Schopenhauer claims that his philosophy embodies a set of 'truths' (1969, vol. 2, p. 185/1949b, p. 206), yet not in the sense that it presents a system of conclusions derived deductively from true premises, nor because it relies on some form of privileged intuition. Rather, it is true in virtue of providing, in contrast to science, an 'understanding' (Verständniß), 'interpretation' (Auslegung), or 'deciphering' (Entzifferung) of the world of phenomena which is, so he claims, rich, satisfying and complete (1969, vol. 2 pp. 184-186/1949b, pp. 204-205). It is such a humanly satisfying interpretation of existence that, according to the arguments of The Birth of Tragedy, only art can provide. Nietzsche picks up on those elements of The World as Will and Representation which can be redeployed creatively in order to support this insight. The presentation of Schopenhauer which results from his refashioning is, admittedly, partial and one-sided. It may nevertheless be concluded that The Birth of Tragedy extends Schopenhauerian themes and concerns in order to hammer its message home.

The Birth of Tragedy's co-option of Schopenhauer extends further than this, however. Nietzsche does not stop at drawing upon his predecessor's arguments in order to announce the crisis of science; he also dramatizes this crisis and casts Schopenhauer in a leading role. He does so by constructing a narrative which has its beginnings in sixth-century Greece, and which locates Schopenhauer-along with Aeschylus, Sophocles, Euripides, Socrates, Kant, and Wagner-at points along a cultural development that will culminate in a new form of tragic art. ${ }^{11}$ This chronology is putatively historical, but insofar as it may be characterized as a form of illusion that aims, via a representation of the past, to generate a constellation of

11 This comment assumes that the 'rebirth' of tragedy Nietzsche envisages in The Birth of Tragedy is, indeed, a Wagnerian Renaissance. Although this has sometimes been questioned, it still seems to me the best way to make sense not only of The Birth of Tragedy but of the references to Wagner in Nietzsche's notes and letters of the early 1870s. The scope of the rebirth Nietzsche has in mind is, however, far too broad and indeed open-ended to encompass Wagner alone. Although Wagner is identified with the fulfilment of this ideal in The Birth of Tragedy, this is compatible with the view that he later retracted this association and, as occurred in Ecce Homo, disavowed The Birth of Tragedy's Wagnerianism without disowning the 'hope' that speaks out from the work (EH III BT 1 and 4). 
beliefs and attitudes that legitimate a particular form of cultural activity, it might more aptly be termed ideological. Its function is to alert its readers to the climacteric shift taking place in European culture and to raise their hopes for tragedy's rebirth.

Nietzsche's most general verdict on Schopenhauer's significance within this narrative comes in The Birth of Tragedy sections 18 and 19, when he is describing the disintegration of the Socratic-optimistic outlook:

The catastrophe slumbering in the womb of theoretical culture is gradually beginning to frighten modern man ... Meanwhile great natures with a bent for general problems have applied the tools of science itself, with incredible deliberation, to prove that all understanding, by its very nature, is limited and conditional, thereby rejecting decisively the claim of science to universal validity and universal goals. Thanks to this demonstration it has been recognized for the first time that it is a delusion [Wahnvorstellung] to believe that we can penetrate to the innermost essence of things by following the chain of causality. The hardest-fought victory was won by the enormous courage and wisdom of Kant and Schopenhauer, a victory over the optimism which lies hidden in the nature of logic and which in turn is the hidden foundation of our culture ... This insight marks the beginning of a culture which I now dare to describe as a tragic culture. Its tmostimportant feature dies în patting wisdom in place of science as its highest goal. (BT 18, KSA 1, pp. 117-118)

Let us recall then, how Kant and Schopenhauer made it possible for the spirit of German philosophy ... to destroy scientific Socratism's contented pleasure in existence by demonstrating its limits, and how this demonstration ushered in an incomparably deeper and more serious consideration of ethical questions and art, one which can be defined as the conceptual formulation of Dionysiac wisdom. In what direction does this mysterious unity of German music and German philosophy point, if not towards a new form of existence, the content of which can only be guessed at from Hellenic analogies? (BT 19, KSA 1, p. 128)

In these remarks, Schopenhauer is lauded (alongside Kant) for having demonstrated the bankruptcy of the Socratic attempt to view the world as amenable to human understanding. The philosophers are not praised for their residual hope for a form of knowledge that transcends the bounds of experience, but rather because of the demonstration their arguments furnish of those very bounds. Although it is Socrates whom Nietzsche dubs 'the vortex and turning point of so-called world history' (BT 15, KSA 1, p. 100), in The Birth of Tragedy 18 and 19, Kant and Schopenhauer appear almost as important as actors on the world-historical stage. In finally discrediting Socratism, they clear the way for the replacement of corrosive scientism with a 'new form of existence': a renewed kind of artistic orientation to the world. Schopenhauer is significant in this story not as the last metaphysician, but rather as the philosopher who demonstrates the need for 
a new myth and who anticipates its form. ${ }^{12}$ In doing so, he merits praise as an augur of the rebirth of tragedy. His successor, both in this prophesying and in this anticipating, is Nietzsche himself.

This paper has tried to rehabilitate some claims about The Birth of Tragedy which may seem rather traditional: namely, the positive character of its appropriation of Schopenhauer and Wagner, and the importance of the (quasi-)historical structure of its argument. Being traditional does not, of course, amount to being mistaken, and I hope I have shown that such claims can be supported by crediting Nietzsche with a less naive reception of Schopenhauer than has sometimes been suggested. Nietzsche famously warns philosophers to be vigilant about the unnoticed and subtle commitments inherent in the grammar of our language (BGE 2, KSA 5, p. 54; TI "'Reason" in Philosophy' 5, KSA 6, p. 78), but the manner in which the areas and positions of long-running debates come to be defined may occasionally be just as insidious. ${ }^{13}$

\section{authors copy with permission by WdG 2008}

\section{References}

Barbera, Sandro, 1994, 'Ein Sinn und unzählige Hieroglyphen. Einige Motive von Nietzsches Auseinandersetzung mit Schopenhauer in der Basler Zeit', in: Tilman Borsche / Federico Gerratana / Aldo Venturelli (eds.), Centauren-Geburten. Wis-

12 As Nietzsche emphasizes in BT 16, it is Schopenhauer's analysis of the representational and expressive capacity of music which also provides an intimation of the kind of art by means of which the crisis can be overcome. Schopenhauer's writings suggest that a work of art which combines music with images or action can represent 'the innermost kernel preceding all form, or the heart of things' (Schopenhauer 1949a, p. 311, quoted by Nietzsche, BT 16, KSA 1, p. 106). This is, of course, the kind of representation Nietzsche characterizes as myth: 'the symbolic image ... with the highest degree of significance' (BT 16, KSA 1, p. 107). Regrettably, space considerations preclude any further discussion of this aspect of Nietzsche's appropriation of Schopenhauer here.

13 The research for this paper was begun when I was a Junior Postdoctoral Fellow in the Institute of Greece, Rome and the Classical Tradition at the University of Bristol, UK. I am grateful to the Institute Board for funding my research and to the Bristol Classical Seminar for their responses to an early presentation. I also owe thanks to Martin Ruehl, Raymond Geuss, Mike Levene, and Thomas Brobjer for their comments and questions on my initial conference paper, and to Nicholas Jardine and Dawn Phillips for subsequent constructive criticism. 
senschaft, Kunst und Philosophie beim jungen Nietzsche, Berlin: Walter de Gruyter, pp. 217-233.

de Man, Paul, 1979, Allegories of Reading: Figural Language in Rousseau, Nietzsche, Rilke, and Proust, New Haven: Yale University Press.

Gombrich, E. H., 1985, 'The Symbol of the Veil: Psychological Reflections on Schiller's Poetry', in: Peregrine Horden (ed.), Freud and the Humanities, London: Duckworth, pp. 75-109.

Lacoue-Labarthe, Philippe, 1971, 'Le detour', in: Poétique, 5, pp. 53-76.

Montinari, Mazzino, 1980, Nietzsche lesen, Berlin: Walter de Gruyter.

Nehamas, Alexander, 1985, Nietzsche: Life as Literature, Cambridge, MA: Harvard University Press.

Oehler, Max, 1942, Nietzsches Bibliothek, Weimar: Gesellschaft der Freunde des Nietzsche-Archivs.

Porter, James I., 2000a, The Invention of Dionysus: An Essay on The Birth of Tragedy, Stanford, CA: Stanford University Press.

Porter, James I., 2000b, Nietzsche and the Philology of the Future, Stanford, CA: Stanford University Press.

Schopenhauer, Arthur, 1864, Aus Arthur Schopenhauer's handschriftlichem Nachlaß. Abhandlungen, Anmerkungen, Aphorismen und Fragmente, ed. Julius Frauenstädt, Leipzig: F. U. Brockhaus.

Schopenhauer, Arthur, 1949a, Die Welt als Wille und Vorstellung, Erster Band, in: Arthur Schopenhauer, Sämtliche Werke. Nach der ersten, von Julius Frauenstädt besorgten Gesamtausgabe neu bearbeitet, ed. Arthur Hübscher, vol. 3, Wiesbaden: Eberhard Brockhaus-Verlag, with permission by WdG 2008

Schopenhauer, Arthur, 1949b, Die Welt als Wille und Vorstellung, Zweiter Band, in: Arthur Schopenhauer, Sämtliche Werke, ed. Arthur Hübscher, vol. 4, Wiesbaden: Eberhard Brockhaus Verlag.

Schopenhauer, Arthur, 1960, 'Versuch über das Geistersehn und was damit zusammenhängt', in: Arthur Schopenhauer, Parerga und Paralipomena. Kleine philosophische Schriften, Erster Band, in: Arthur Schopenhauer, Sämtliche Werke, ed. Arthur Hübscher, vol. 5, Wiesbaden: Eberhard Brockhaus Verlag, pp. 239-329.

Schopenhauer, Arthur, 1969, The World as Will and Representation, trans. E. F. J. Payne, 2 vols., New York: Dover.

Schopenhauer, Arthur, 1974, 'Essay on Spirit-Seeing and Everything Connected Therewith', in: Arthur Schopenhauer, Parerga and Paralipomena: Short Philosophical Essays, trans. E. F. J. Payne, vol. 1, Oxford: Clarendon Press, pp. 225309.

Skinner, Quentin, 1969, 'Meaning and Understanding in the History of Ideas', in: History and Theory, 8, pp. 3-53.

Staten, Henry, 1990, Nietzsche's Voice, Ithaca, NY: Cornell University Press.

Wagner, Richard, 1911, 'Über Staat und Religion', in: Richard Wagner, Sämtliche Schriften und Dichtungen. Volksausgabe, Sechste Auflage, vol. 8, Leipzig: Breitkopf und Härtel, pp. 3-29.

Wagner, Richard, 1995, 'On State and Religion', in: Richard Wagner, Art and Politics, trans. William Ashton Ellis, Lincoln: University of Nebraska Press, pp. 5-34.

\section{Translations}

The Birth of Tragedy, ed. Raymond Geuss, trans. Ronald Speirs, Cambridge: Cambridge University Press, 1999. 
authors copy with permission by WdG 2008 
Index rerum et nominum

authors copy with permission by WdG 2008 
authors copy with permission by WdG 2008 
A

Abel, G., 10, 18, 122, 132-134, 142143

Absichtlichkeit, 130

absolute, V, 3-4, 10, 77, 114, 123-

124, 128-129, 137-138, 155, 233, 306

Abstammungslehre, 28, 32

abstraction, 49

absurd, 69, 122, 155, 164-167, 187

acquaintance, 23, 214, 231

activity, 53, 65, 72, 130, 179, 198,

223-225, 235, 286

acts of intending, 95

actuality, 3, 79, 158

adaptation, 13, 28, 68, 70-72

adaptive-pragmatic, 9

Adorno, Th. W., 238, 264

adualism, 113-146.

adualistic-dialetheic, 2, 9, 10-11

Aeschylus, 215, 219:286

aesthetic, 160, 186, 199, 218, 232,

$234,239,256,306$

aestheticism, 243

affect, 71-72, 84, 97, 129, 304

affirmation, 14-15, 113, 139, 149,

151-155, 161, 166-167, 180, 183-

$184,195,199-202$

afterlife, 25, 165

Afterphilosophie, 247

agency, 10, 16, 85, 96, 102, 108, 125, 248

aggressive, 99, 258

agon, 203-209

agonal law, 209

agonistic, 15, 17, 151, 153-154, 161, 260

ahistorical, 241, 247

Ajax, 39

alchemy, 140

Alcibiades, 37

alienation, 196

alternatives, 9, 12, 136-137, 142

Altertumswissenschaft, 16, 213, 214

Alteuropa, 236

altruism, 68, 136

ambiguity, 1, 196-199

amor fati, 150 amoral, 257, 261

amoralism, 239

anaesthesia, 124

anarchists, 174

Anaxagoras, 137

Anderson, R. L., 176, 189

Andler, C., 232, 246, 264

anglo-analytic, 11

anomalous, 102, 120

anomaly, 14, 113

anthropocentric, 135

anthropological, 1, 8

anthropomorphic, 285

anti-humanist, 16, 233, 255, 264

Antike, 266

anti-liberal, 16, 233, 255

antiquarian, 16, 51, 213-226

antiquity, 16, 43, 44, 215-226, 233, 240, 243, 246-249, 252, 259

Antisemitismus, 269

antistoricismo, 227

Aspollonian, 159,234, 276-278

appearance, 3-4, 24, 45, 79, 85, 120, $125,151,155,164,193,201,220$, 231, 276-280, 284

approximation, 41,121

Ardinghello, 233-234, 239, 267

argument from anxiety, 8

aristocratic, 16, 139, 251-256

Aristophanes, 38

Aristotle, 40, 47, 222

art, 45, 103, 122, 140, 159, 160, 177, 201-202, 220, 234, 237-238, 243, $248,253,256,257,258,261,263$, 283, 285, 286, 287, 292, 295

artist, 55, 77, 121, 159, 201, 234, 238, 257

artistic, 15, 38, 55, 104, 159, 160, 201, 222, 234-235, 256-258, 278, 287, 291

artworks, 122

ascetic, 15, 54-56, 97, 100-101, 107,

$138,152,164-166,169-175,181-$

182,260

asceticism, 15, 26-27, 154, 166

Aschheim, S. E., 262, 264

Asian, 30

asymmetrical, 132

atemporal, 2, 80 
atheist, 257

Athenians, 42, 44

atom, 127,129

atomistic, 196, 202, 209

Aufklärung, 269

Auflösungsprozess, 116

Augustine, 26-27, 155

Aunger, R., 72-73

autopoesis, 3

auto-sensitization, 4

awareness, 8, 79, 83, 106, 127, 133, 189

B

Bächtold, H., 254, 264

backwards-willing, 185-188

Baldwin, G., 233, 264

Barbera, S., 198, 210, 280-281, 288

Barkow, J., 64, 73

Barth, H., 232, 265

Bauer, S., 248, 254, 265, 270

Baumgarten, F. Fo, 263,265copy with permiss257-263WdG 2008

Baumkultus, 25, 32

beauty, 24, 199, 233, 262-263

becoming, 3-8, 14, 75, 85, 91, 113$142,151-155,161,164,170,191$, $198,200,217,224-226,231,250$

Beeckman, T., IX, XI, 13, 18, 63-74

Beethoven, 243, 244, 282

being, 3-7, 14, 25, 42, 52, 54, 57, 64, $67-68,71,75-76,78,81,83,85$, $89,91,102-103,106,108-110$, $113-142,151,154,159,161,167$, $169,172,173,176-178,182,184$, $186,187,191-194,197-200,203$, $215,217,227,243,246,261,278$, $285,288,302,305$

benevolence, 109

Benz, E., 251, 265

Berg, Ch., 254, 265

Bergk, Th., 215

Bergmann, P., 241, 244, 265

Berkeley, 35, 49, 50, 82, 84, 264, 272

Berkowitz, P., 181, 189

Berlin, I., 40

Bernhardy, G., 216, 229

Bertram, E., 249, 265

besinnen, 4-5

Bewegungen, 269

brain, $11,13,75-80,282$
Bewusstsein, 198

Biedermeier, 238

Bildungsbürger, 240

Bildungstrieb, 123

Bildungsvereine, 254

binary thinking, 3, 151

biology, 23, 67, 71-72

Bismarck, 239, 241, 270-271

Bizet, 37, 292-294

Blackmore, S., 70-73

blame, 239

blasphemous, 239, 257

Bluhm, H., 249, 265

body, 25, 32, 101, 125-126, 131, 160, $167,194,209,304$

Boeckh, A., 213-217, 221, 223, 226

Boeschenstein, H., 255, 265

Bohley, R., 251, 265

Borcherdt, H., 234, 265

Borchmeyer, D., 242, 244, 249, 265

Borgia, C., 233, 236, 238-239, 250,

Boscovich, R., 82

both-and, 11

bourgeois, 234-240, 254, 260

Bowie, A., 121, 143

Boyd, R. 72, 74

Brahmanistic, 28

Brecht, 234, 265

Brobjer, IX, XI, 13, 18, 51-60, 219, 227, 232, 241-242, 265, 288

Brose, K., 232, 265

Brown, G., 67, 73

brutality, 237, 239

Buddhism, 28, 127, 182

Bullen, B., 235, 266

Burckhardt, J., X, 16, 19, 30-32, 52, 58, 200, 231-272

Bürgerhumanismus, 240

burials, 25

Bursian, C., 216, 227

Byzantium, 91

C

cadence, 295, 296

Calder III, W. M., 227-228

Callebaut, W., 71, 73

Campioni, G., 213, 227, 242-245, 266 
Camus, A., 15, 163-168, 171, 183, 186-189

Cancik, H., 241, 244, 254, 266

Carmen, 292-295, 301

Cartesian, 8, 10, 48, 123

Catholic, 231, 250-251

causal, 8, 42, 46, 93, 97, 129, 132,

$152,155,185,282$

causality, 75-76, 84, 97, 125, 130, 287

Cavell, S., 195, 210

centripetal, 202

Cesana, A., 244, 266

Cesare Borgia aestheticism, 262

C-fibres, 11

chaos, 2-3, 140, 178, 276, 297, 302, 304

chemical, 9, 125

Choephoren, 219

choral, 160, 244, 292

chorus, 222, 275

Christentum, 269-270, 272

christianisme, $25_{2} 33$ hors copy v

Christianity, 12, 24-31, 47, 94, 239, 243, 250, 259-260

chronophile, 7

chronophobia, 4

Cicero, 44

circularity, 155, 185, 276

civilization, 12, 24, 25-30, 170, 233264

Clark, M., 33, 111, 124, 143, 144, 188, 189

classic, 47, 71, 258, 292, 301

classical philology, 89, 213, 241, 244, 252

coercive, 207-208

coexistence, 12, 31-32

cognition, 10, 48, 78, 80, 81, 82, 93, 95, 96, 99, 134, 154, 156, 279

Cohen, J. R., X-XI, 17-18, 33, 291307

Cohen, M. D., 215, 228

cohesion, 94, 139

comedy, 260

commands, 99, 165, 185, 189

communism, 254

Communist Manifesto, 235

community, 16-17, 25-27, 97, 135-

136, 139, 201, 209 compassion, 139

competing powers, 207

competition, 101, 205

complementarity, 307

completeness, 204

complexity, 14, 26, 29, 67, 114, 131, 135,217

composition, 3, 243, 296

Conant, J., 195, 210

conceptual, V, 28, 114, 150, 160, 281, 287

condottieri, 233, 237, 256

confederation, 127

conflict, 12, 35, 42, 48, 88, 111, 115 , 153, 196, 199, 202, 208, 209, 217. 307

conformity, 194, 201

conscience, 92, 99, 136, 193

conscious, 4, 54, 69, 79, 92, 95, 99,

$106,129,130-134,142,159,165-$

$167,185,187-188$

iconsciousness, 44, 10,018 46, 72, 76,

$93,123,124,128,134,165-166$,

181, 185, 187, 280

conspirieren, 126

contentious contentment, 140

contest, 151, 203-207, 227

continental, 11, 135

continuum, 30, 125, 131-132

continuum-relations, 134

contradiction, 5, 9, 15, 52, 65, 73, 91, 105-106, 166, 191, 207

Conway, D., 195, 204, 210

Corcyra, 44-45

Cosmides, L., 73

cosmological, 14-15, 149, 154, 160, 185

cosmos, 59, 82, 186

counter-force, 14, 113, 117-118, 135, $141,151,209$

counter-ideal, 15, 57, 169, 171-172, 180,182

Craig, G., 234, 266

creative, 17, 127, 156-159, 175-176, $180,192,196,201,205,208,223-$ 224, 247, 295

creativity, 73, 156, 206

creator, 85,258

creator-god, 48 
crime, 198, 256, 261

critical history, 51

crystallization, 16, 233, 292, 297

cultivation, 46

cult, 25-26

culture, 16, 26, 31-32, 39, 45, 47, 51, 53, 58, 63-65, 70-72, 90, 104, 119, $150,158,196,199,201,203,222$, 226, 233, 235, 240-249, 252-256, 262-264, 286, 287

custom, 94, 97, 99, 170, 191

cycle, 188-189

cyclic repetition, 154-157

$D$

da Romano, E., 236

dancing, 65, 159, 295, 304

Danto, A. C., 123, 128, 143

Darwin, Ch., 13, 28, 64-73, 89, 93

Darwinism, 53, 66-72, 87, 92-93, 111

Darwinizing, 73

de Man, P., 17, 276, 288 rs copy with perm death, 38, 40, 45, 104, 138, 150-152,

$155,164-170,175,181-188,250$, 260

death of God, 104, 151-152, 175

death of Socrates, 38

decadence, 41, 85, 119, 172, 174, 241

decadent, 15, 58, 124, 138, 168-169,

172

decay, 85, 209, 260, 292

deconstruction, 16, 173, 248, 276

deferral, 209

degenerating, 15, 119, 167, 169-171

deity, 85

Deleuze, G., 69, 73, 125, 143

democratic, 208, 253

democratization, 254

Demokratie, 269

Dennett, D., 68, 71-73

Derrida, J., 139, 143

desire, 3, 5, 40, 54, 69, 73, 88, 94, 97,

117, 124, 164, 170, 175, 179, 199,

201-202, 209, 222, 236, 250, 254, 279, 292, 296

despotic rulers, 236

destruction, 41, 44, 80, 85, 141, 156, $205,222,256$ destructive, 18, 40, 119, 170, 182, 196, 198, 222, 304

Detwiler, B., 256, 266

Deussen, P., 28, 32

diachronic, 127, 192, 247

dialectical, 3

dialetheic, 10

Dialetheism, 9

difference-preserving, 11

differential, 70, 138

dilemma, 103, 135-136

Dionysian, 76, 124, 141, 159-160, $219,234,262,275-283$

Dionysus, 38, 278, 289

directednesses, 95

diremption, 196

disembodied, 185, 264

disgregation, 129, 135, 196, 209

disjunction, 3, 15, 120-121

dissatisfaction, 156, 164

diversity, 15, 202-206

Bodds, E, R.,47,49008

dogmatic, 12, 48, 123

Dombowsky, D., 258, 266

Donnellan, B., 247, 266

doubleness, 138

doubt, 5, 56, 79, 122, 126, 170, 187. 241, 256, 260, 263, 280

Draper, J. W., 24, 32

dream, 177, 278, 281, 282

Dries, IX, XI, 1-19, 14, 18, 19, 113-

145, 114, 135, 143, 144, 189

drives, 32, 54, 66, 92-110, 131, 152, 194, 222

dualism, 14, 114, 120-123, 130

dualistic, 113, 137, 138

duality, 49, 137, 139

Dühring, 56

duration, 65, 114, 123, 133-134

dwarf, 105, 182, 187

dynamic, 120, 126, 129, 151, 191, 195-196, 203, 205-206, 207

E

early modern, 231-236, 240, 244, 246, $253,255,257-259,261,263$

earth, 56, 89, 153, 170, 174-175, 186, 201,295

ecstatic nihilism, 116, 119, 183 
educators, 197

efficacy, 94, 116, 123-124, 132, 222

egalitarian, 52, 203, 260

ego, 91

egocentric, 203

egoism, 234, 283

Egypt, 91

Egypticism, 85

Einheit, 128, 132, 202

einverleibt, 6, 133

either-or, 10, 135-140

elitism, 253, 255

emancipation, 194, 200, 202, 240,

244-245, 249

embodied, 25, 160, 167, 183, 239, 252

Emden, Ch. J., 115, 143

Emerson, W., 15, 195, 197, 210

emotional force, 159

emotions, 42

empirical, 10, 47, 75, 78, 81-82, 150

empirically real, 81

empiricism, 252

encounters, 117,125

endless melody, 17, 291-292, 295-

297, 300-304, 307

Enlightenment, 196, 234, 246, 264

epiphenomenal, 9, 252

epistemological, 53-54, 152, 157, 223

equality, 208, 254-255

Erasmus, 244, 271

Ernst, J., 239, 266

error, 4-10, 36, 95, 102, 121, 157, 300

error theory, 4-5

essence, V, 3-4, 27, 54, 65, 114, 122,

125-126, 182, 186, 213, 249, 252,

262, 281, 287

essentialism, 132

eternal novelty, 156

eternal recurrence, 14-15, 56-57, 127,

141, 149-161, 174, 180-189

eternal return, 87-90, 105, 110-111,

183

eternity, 105, 151, 186, 189, 204, 207

ethical, 6-7, 16, 37, 39, 42, 47-48, 66,

204, 206, 209, 234, 239, 246, 287

ethics, 47-48, 191, 260

etiological, 93

Euclideans, 77

Euripides, 38, 160, 286
Europe, 7, 43, 56, 235-238, 244, 251, 253-255, 257, 260, 262, 267

evolution, 28, 53, 63-67, 69-72, 92, 97, 253

evolutionary history, 133

evolutionary psychology, 64, 68, 73

exaptation, 68

excellence, 4, 35, 193, 238, 246, 295

excess, 232, 261

excitation, 11, 56

exhaustion, 167,170

existence, 2-3, 6, 48, 53, 67, 69, 70, 77-82, 88, 92, 98, 114, 126, 137, $150-151,153,155,165,167,169$, 174-176, 178, 180-181, 184-186, 189, 194-195, 198-199, 237, 244, 278-279, 281, 285, 287, 303, 306

existentialist, 165, 167, 183-184, 305 exogenous, 115

experiential, 10-11, 124

experiment, 117, 149

iexternalism, 95 i G 2008

F

factual, 42, 149, 157

factuality, 58, 158

faculties, 281

fallacy, 8,68

falsehood, 198, 218

falsification, 15, 77, 82, 121, 131, 178

Farulli, L., 246, 253, 266

fatalism, 137

fate, $43,46,115,175,187,188,201$, 241

fatigue, 117, 119, 169, 171

Faustian, 239

feeling, 1, 27, 29, 41, 90, 95, 98-99, 118, 136, 181, 195, 203, 225, 243, 261, 279, 281-282, 292, 295

Ferguson, W. K., 233-235, 240, 266

fiction, 8, 10, 127, 157, 160, 234, 239

fictionalist, 9

Figal, G., 125, 143

fighter, 201, 204

fighting, 238

Figl, J., 128, 143

figurative, 158, 284

finitude, 152, 155, 193

first-person perspective, 9-10, 142 
fitness, 70, 94

fixation, 87,89

fixed, 1, 102, 118, 126, 151-152, 179, 197,282

fixity, 158

flourishing, 17, 171, 295

flow, 83, 91, 123, 186, 225, 292

flux, 119-120, 123, 128, 133, 138, $141,152,158,209$

force, $\mathrm{V}, 15,29,64,68-71,77,82,93$, 107-109, 116-118, 121, 125, 127, 129-154, 156, 159, 161, 166, 178, 183, 191, 197, 201-204, 207, 223, 232, 234, 237, 242, 246, 249, 256, 259, 282, 292

Ford, A., 41, 49

forgetfulness, 88

forgetting, 103, 179

formless, 244

Förster-Nietzsche, E., 245, 266

Foucault, M., 31, 32, 63, 69, 73

foundation, $51,56,124,151_{1}, 233,241_{\text {t }}$ 255, 287

Fowler, R., L., 220, 227

fragility, 135

framework, 7, 9, 10, 11, 135, 177, 179, 191, 206, 241, 259

Frank, M., 121, 127, 143

free spirit, 199, 209, 245, 257

freedom, 87, 95, 105, 108-110, 156, $165,175,184,194,199,201-202$, 208, 232, 251, 295

Freeman, A., 10, 18, 19, 131, 143

Frege, G., 124

Freigeist, 266

Freiheit, 144

Freud, S., 37, 183, 288

Froben, J., 244

Frühromantik, 143

Fubini, R., 240, 263, 267

fundamental-duality, 11

G

Ganze, 115, 135

Gay, P., 232, 238, 267

Gegenkraft, 113, 116, 117, 141

Gegensatz, 10

Gelzer, H., 239, 267 genealogy, 4-7, 14, 63-71, 88, 92, 95$96,98,102-110,119,124,193,234$ genius, 26, 37, 135, 199-202, 204, $239,242,246,248,264,284$

genotype, 72

Gerechtigkeit, 202

Gerhardt, V., 121, 143, 192, 195, 200, 202, 204, 210, 213, 228, 243, 260, 267

German culture, 204, 241, 250

German Darwinism, 67

Germanen, 25, 32

Germanic, 241, 243, 264

Germany, 28, 91, 218, 231-234, 252, 254, 262-264, 270

Geschichte, X, 16, 18, 24, 32, 213, 216, 226-228, 265-272

Geuss, R., VII, IX, XI, 12, 18, 35-50, $63,73,142,288,289$

Gilbert, F., 235, 267

Gilbert, M., 232, 267

Gleichheit, 136, 208,0258

Gleichmachung, 208

goal, V, 1, 13, 28, 52, 92, 119, 125, $126,129,137,174-178,181,185$, 188-189, 209, 215, 222, 225, 285, 287

godless, 155, 172, 239

Goethe, J. W. von, 16, 136, 143, 214 $215,226,228,234,239,243,259$, 268,284

Gombrich, E. H., 284, 288

Gomme, A. W., 43, 50

Gossman, L., 232, 236, 241, 254, 258, 267

Gottfried, P., 267

Gould, S., 68, 73

Greece, 41, 91, 158, 220, 243, 246, 248, 252, 286, 288

Greek, XIV, 9, 12, 16, 24-25, 28, 43$47,59,79,155,157-160,174,192$, 203, 220-222, 226, 233, 243, 245, 247, 256, 270-271

Gregor-Dellin, M., 249, 267, 271

Grey, J., 18

Gründer, K., 220, 226, 228

guilt, 47, 99, 102, 165 
$H$

Habermas, J., 196, 210

habituated, 8,10

Hale, J. R., 237, 267

Hales, S., 127, 143

Hampe, K., 257, 267

Hankins, J., 240, 267

happiness, 5-6, 12, 39, 48, 88, 150, 173, 194, 261

Hardtwig, W., 235, 267

Harloe, X, XI, 17, 18, 275-289

harmonic, 292, 296, 302

Harnack, A. von, 27, 31-32

Hatab, L. J., IX, XI, 10, 14, 18, 65, 73,

149-162, 168, 185, 190

Haupt, M., 215-217, 220, 272

health, 39, 54, 57, 88, 104-105, 172, $174,181,183,199,223,249,259$, 304

Hector, 39

hedonist, 55

Hegel, G. W. F., 2-4 4 , 18, 37, 64, 11 15, $120,124,139,143,196,247,284$

Heidegger, M., 31, 32, 210

Heinse, (J. J.) W., 233-234, 239-240, 265, 267, 272

Hellene, 13, 48, 160

Hellenic, 25, 38, 58, 203, 246, 278, 287

Heller, E., 232, 267

Heraclitean, 7, 10, 121, 137, 202

Heraclitus, 134, 137-138, 203

hereditary, 28

heredity, 70

hermeneutics, 122

heterogeneous, 23-25, 29

heteronomy, 195, 204

hierarchical, 255

hierarchy, 102, 276

Higgins, 306, 307

Hill, R. K., IX, XI, 13, 18, 75-85, 269

Hinz, M., 244, 268

Hippocrates, 42, 45

Hirsch, E., 249, 251, 268

historian, 25, 51, 54-58, 216, 221$227,231-234,251,263$

historical, 12-13, 16-17, 23-24, 28$32,38,43,47-48,51-59,67-69$,
$85,87,96,99,101,103,157-158$, 213, 216, 221-222, 226, 232-233, 246, 248, 256-257, 259, 261, 264, 286, 288

historicist, 85

historicity, 5, 221, 224

historiography, 55, 213, 220, 224-226

history, V, 1-3, 7, 10-11, 13, 16, 23, 28-31, 36, 40, 42-47, 49, 51-59, 63, 65-68, 72, 87, 89, 91, 94, 96101, 121, 157-158, 161, 170, 174, 184, 186, 191, 201, 213-215, 219, 223-224, 227, 231-234, 244, 247248, 251-252, 262-263, 275, 287,

See ahistorical, critical history, evolutionary history, historian, historicism, historicity, historiography, overhistorical, prehistoric, prehistory, superhistorical, suprahistorical, time, unhistorical.

ifofmann, $\mathrm{H}_{\text {. }}$ 241, 2688

Hölderlin, F., 215

holistic, 161, 216, 225

Homer, 42, 203

homogeneity, 29, 94

homogenization, 136

homogenous, 30, 255

hope ( $\left.\dot{\varepsilon} \lambda \pi i \varsigma^{\prime}\right), 40$

Houlgate, S., 120, 143

human animal, 15, 164, 170-171, 174, 176, 178-183, 186-188

human existence, 151, 175-176, 179, 186

humanism, 232, 240, 243, 251, 255

humanitas, 240, 259

humanity, 64-66, 92, 94, 96, 116, 119, 201, 255, 260, 262

humankind, 94, 170-175, 182, 184

Humboldt, A. von 214

hypostases, 125

I

idealism, 76, 79-80, 82, 104

idealization, 234, 237

identity, 27, 102, 106, 114, 120, 126,

$127,135,233,237,257$

illness, 138, 169, 174

illogical, 136 
illusion, V, 1, 5, 43, 51, 102-103, 119, 199-200, 223, 281-283, 286

illusory, 3, 7, 121, 124, 199, 278, 285 imagination, 47, 233, 260

immanence, V, 1, 155, 175, 198, 201, 280

immoral, 85, 238, 261

immoralism, 172, 232-236

impermanence, 3,113

impulse, 49, 65, 195, 201, 213, 223, 226, 244, 281

incoherent, 36, 81, 82

inconsistency, 8, 118, 119-122, 141

incorporated, 6, 10, 109-110, 131,

133,140

indeterminacy, 3, 123

indetermination, 120,128

indifferent, 29, 39, 136

individualism, 17, 193, 233, 238-240,

$253,255,261,263$

inheritance, 67, 70-71, 77, 233, 237

innocence of becoming 115,119

inorganic, 131-134

instinct, 93-94, 97, 104, 140, 164,

$167,171,175,222,224,257,283$

instinctive, 58

intellectual, 53, 172, 231-232, 239-

$240,244-245,263,281$

intelligence, 36

intentionality, 92-93, 105, 122, 130-

131

interconnected, 35, 276

interdetermination, 128

interpretationism, 132

intersubjectivity, 306

interweavings, 23,30

intoxication, 124

intuition, 76-77, 134, 224, 286

involuntary, 47, 161

irony, 276

irrational, 247

irreducibility, 160-161

isomorphic, 129

$J$

Jacobs, A., 234, 268

Jahn, O., 213-228

Janssen, E. M., 232, 234, 239, 251-

$252,255,257,261,268$
Janz, C. P., 244, 268

Jeismann, K.-E., 254, 268

Jelavich, P., 263, 268

Jensen, A. K., X, XI, 16, 18, 213-229

Jewish, 27, 31, 174, 245

Joël, K., 248, 268

Judeo-Christian, 7, 85

judgement, 37, 44, 46, 96, 132, 195 , 198-199, 220, 223, 225, 236, 239. 257-258, 261

Jung, M., 248, 268

justice, 15, 29, 83, 115, 173, 202, 223, 236, 254, 296

K

Kaegi, W., 231-239, 244-248, 251, 256, 258, 261, 268, 272

Kahan, A., 236, 268

Kant, I., 13, 47-48, 75-85, 89, 110, $135,143,160,275,280,284-287$, 305-306

iKaintianism, /77, 792008

Katsafanas, P., 127, 143

Kitcher, P., 64, 73

Knobe, J., 10, 18, 132, 143

knowability, 8

knowable, 81

knowledge, 11, 35, 39-40, 48-49, 52, $75,79,83,92,100-101,106,150$, 209, 215, 242, 275, 279-284, 287

Körner, E., 233, 269

$L$

La Rochefoucauld, F. de, 247, 266

Lachmann, K., 213, 216-218, 221222

Lacoue-Labarthe, P., 276, 289

Ladwig, P., 240, 269

Laland, K., 67, 73

Lamarck, J.-P. de, 13, 64-71

Lange, F. A., 285

Langer, S., 304, 307

language, 11, 14, 26, 44, 65, 93, 114, 120-123, 125, 128-130, 133, 142, 157-159, 201, 209, 214, 226, 262263, 275-277, 282, 284, 288, 292, 295,306

Large, D., 145, 241, 269 
laughter, 185

law, 10-11, 15, 25, 67, 98, 127, 191209,256

law-givers, 198, 204-206

Lecky, W. E. H., 25, 27, 32, 66, 74

legislator, 192, 199, 203-204

legislators, 192, 204, 209

legislator-types, 192

Leiter, B., 10, 18-19, 33, 132, 143, $144,166,169,183-184,190$

Leo, H., 234, 236, 269

leveller, 206

levelling synthesis, 138

liberalism, 260

liberty, 172, 234, 236, 238, 239, 240

Lichtenberger, H., 266

life as lived, 15, 156

life-affirmation, 15, 26, 150-156, 161, 168-169, 171-172, 180-181, 184,

188, 199, 200, 203

life-as-becoming, 15, 191

life-denying, 152-154, d66, 169, 171 260

listen, 295, 297, 304

listener, 17, 160, 244, 292, 296-297, 301-303, 307

literal, 5, 149, 154, 156-162

literality, 14, 149, 158

Loeb, P. S., IX, XI, 15, 18, 163-190

logic, 7, 9-10, 117, 127, 134, 137142, 165, 167-168, 188, 287

logic of alternatives, 137

logocentric, 276

Lothar, R., 262-263, 269

love, 27, 116, 135, 139, 142, 154, 164, 172-173, 177, 197, 201, 207-209, 260, 296

Löwith, K., 256, 269

Luther, M., 16, 241, 243-244, 248$251,265,268$

$M$

Machiavelli, N., 237, 239, 242-243, 256-258, 271

Macht, 142-144, 200, 210, 241

macro-teleological, 3-4

Magee, B., 296, 307

maladaptive, 68

Mann, Th., 244, 262, 266, 269-270
Mannhardt, W., 25, 32

Marti, U., 254, 269

Martin, A. von, 232, 237, 239, 245,

248, 258-259, 263

martyrdom, 27

Marx, K., 235

mask, 54, 135

mass, 171, 255, 262

massification, 254

master, 125, 130-131, 170, 224, 226, 259

materialism, 236

mathematical symmetry, 292

Mattioli, A., 245, 269

Maurer, R., 232, 269

McGinn, C., 10, 18

meaning, 3, 13-14, 28, 41-44, 48, 57, $59,63,65,68,83,91,94-95,117-$ 118, 120-121, 130, 149-157, 160161, 164-166, 169, 171-188, 192, 194, 197-198, 200, 207, 221, 233, s250, 278, 285, 307008

measures, 17, 151, 292-301

mechanism, 66, 78, 91, 94

medievalism, 244

Melodie, 292

melody, 17, 292, 295-296, 301

meme, 70,72

memetics, 64, 72-73

memory, 87-90, 97-102, 105, 179-

180, 188, 197

meta-belief, 7

metabolism, 304

metaphor, 27, 157, 283, 302-305

metaphysician, 123, 219, 287

metaphysics, 7, 17, 55, 77, 84-85,

120, 123-124, 127-129, 139, 142, 197, 200, 247, 275-285, 303

Methodenstreit, 228

methodological, 13, 16, 68, 216, 225, 252

Meyer, E., 30, 32, 272

Michelangelo, B., 257-258

Michelet, J., 238, 269

micrologists, 222

micro-teleological, 3

Middle Ages, 235, 242, 251-252, 255, 259, 264

Mill, J. S., 53 
mimetic, 158-161

mind, $10-13,43,66,75,78,80,82-$

$84,92,98,100,115,127,131-132$,

$137,154,163,165,184,199,226$,

$250,262,281,284,286$

mind-brain-world state, 11

Mithras, 26

mixing, 12, 29, 31, 32

mixture, 108, 256, 276

mnemonic, 179, 182, 185

mnemotechniques, 89,179

modern, 29, 32, 40, 45, 47, 52-55, 58, 70, 87, 160, 171, 174, 192, 196, 199, 213, 233, 235-238, 240, 243, 246, 250, 254-255, 257-261, 287, 291

modernity, 31, 52, 196, 201-202, 209, 236-237

modesty, 96, 260

Molner, D., 247, 269

moment, V, 3, 69, 71, 91, 102, 109,

$126,132,136,176,179-180,185$, 187-189, 244, 262, 281, 284

momentum, 107

Mommsen, W. J., 51, 256, 269

Mongolian, 24

monism, 11, 113, 134, 137

monstrosity, 258

Montaigne, M. E. de, 247, 269, 271

monument, 104, 257

monumental, 16, 51, 213, 221, 224226, 252, 257

Moore, G., 115, 123, 143

morality, 7, 15, 36, 53, 59, 65-68, 72-

$73,95,98-99,102-103,108,114$,

165, 191, 194-196, 204-206, 209,

231-232, 241, 259, 260, 262, 295

moralization, 39

mosquito, 136

motion, 1, 130, 247

Müller, C. W., 213, 217, 228, 268

Müller-Lauter, W., XIII, 125, 144

multiplicity, 32, 73, 120, 135, 139,

194, 202-203

mummification, 7, 121, 224

music, 17, 27, 37, 159, 178, 201, 218,

226, 241-244, 249, 253, 287, 291-

292, 295-296, 297, 301-304, 306 mutually exclusive, 5-6, 9, 12, 136$137,140,142$

mysterious, 201, 256, 283, 287, 306

mystery, 26

mystical, 285

myth, 39, 140, 160, 186-188, 285-288

mythopoetic, 157

N

Naake, E., 254, 269

Nägeli, K. W., 28, 32

Nancy, J.-L., 10, 18

narrative, 17, 41, 43-44, 64, 131, 176, $185,260,277,286,292$

nationalism, 233

nations, 11, 91, 283

natural science, 4, 52-53, 55, 65, 72,

$76,78,81,115,117-118$

naturalisation, 194

naturalism, 13, 63-65, 73, 75, 78-79,

151,282

Nehamas, AA, 15: 17,0176-180, 190, $233,262,269,275-276,289$

neither space nor time, 77

neither-nor, 11, 138

neo-Romantic, 232

neurobiological, 11

neuroscience, 11

Newtonian physics, 76

Niebuhr, B. G., 51

Nietzscheanism, 262

nihilism, 7, 9, 11, 14, 52, 57-58, 104, 107, 113-119, 127-129, 135, 137,

140-142, 170, 172, 181, 196, 204, 307

nobility, 29, 225

noble, 196, 223, 225, 234, 248, 250,

$255,258-260,264$

nomadic, 91

non-Christian, 3

non-circularity, 39

non-contradiction, 10

nondualist, 11

non-literary, 12, 42

non-mythic, 12, 42

non-permanent, 7

non-reductive, 13-14, 114, 132

non-sensory, 5-6

non-static, 7 
non-theological, 12, 42

non-traditional, 12

Norbrook, D., 251, 261, 269

Nordic, 244

norm, 170

normative, 152

nothingness, 155-156, 164, 172, 176, 181-182, 187

noumenal, 81, 85, 124

novelistic model, 156

$O$

objectivity, 4, 52-54, 58, 104, 117, 239,305

observable facts, 42

observation, $38,157,256,261,275$, 284

observer, 138, 263

Odysseus, 24

Oehler, M., 279-280, 289

Oldenberg, H., 28, 32

Olympus, 160 authors copy with perm omnipotence, 203

omnipresent, 179

oneness, 115, 135-139

ontological, 3, 5-7, 121, 123-124, 127, 276

ontology, 7, 14, 75, 113-114, 117,

$122,128,134,142,191,194$

oppositional, 136, 151

optimism, 12, 17, 39, 41, 47, 49, 225, 287

optimistic, 3, 39-40, 246-247, 282

orality, 158

orderliness, 24

orders, 251, 254

organic, 3, 29, 91, 93, 95, 117, 131134

organism, 10, 68, 71, 94-95, 132, 134, 142

organs, 92-93, 134

originality, 36,89

origins, $23-25,31,48,65,68,90,233$, 237, 280, 282

Orsucci, A., IX, XI, 12, 19, 23-33,

$249,251,270$

oscillation, 3

Osiris, 26

otherness, 139, 153
Ottmann, H., 31-32

Overbeck, F., 27, 31-33, 184

overcoming, 6, 29, 109-110, 114-115, $141,151,155,173-174,182,192-$ 193, 196, 207, 222, 241, 261, 287

overhistorical, 51

$P$

pagan, 25, 27, 30, 257, 259

pain, $6,11,89,99,117,207,256$

painful, 6, 118, 197, 221

painter, 57

painting, 238

Panizza, O., 262-263, 270

panlogicist, 3

panpsychism, 83, 131

papacy, 250-251, 257

paradigm of becoming, 116, 128, 130,

$133,138-140$

paradigm of being, 4, 114, 116, 129 ,

134,137

iparadigm shift, 177 -1) 198

paradoxical, 76, 129, 166, 281

Parmenides, 4, 79, 85, 137

parody, 276

particle, 215, 221

particularism, 15, 194-195, 206, 209

partisanship, 45

passion, 101, 202, 222, 246

passive, 72, 205, 207

Pastor, L., 231-232, 251, 263, 270

paternalism, 236

pathological, 45, 236

pathos, 118, 126, 244, 259

Patroclus, 39

peace, 202, 231

peacefulness, 261

Peloponnesians, 42, 44

penalty, 40

perception, 71, 84, 131, 203, 209, 247, 280, 283-284, 302, 306

perfection, 64, 66, 155, 185, 195-197, 215

perfectionism, 15, 195

performative sense, 158-159

permanent, 3-7, 113, 118, 261, 279

Pernet, M., 251, 270

perspectival, 10, 130-132, 142, 154, 306 
perspective, 10-11, 17, 32, 71, 104, 127, 130-133, 137, 142, 158, 167, 168, 194, 199, 206, 221, 224, 244, $246,261,275,302$ perspectivism, 75, 83, 131, 150, 275 pessimism, 3, 12, 39, 47, 124, 155,

$183,225,241,256,283$

pessimist, 12, 48, 57, 168

Petersen, E., 217, 228 petrifaction, 292, 297 phantasmal, 1, 126 phantasms, 137 phantom, 278, 281 phenomena, 12, 23-24, 28-31, 63, 65, $72,75,123,138,278,284,286$ phenomenal, 76-81, 85, 125, 128 phenomenalism, 82 phenomenological, 11, 123-124, 126$127,135,139,141$

phenomenology, 123-125, 135, 139 phenotypic, 71

philhellenist, $233_{2} 263$

Philistius, 44

philologist, 23, 57, 59, 219, 222, 224, 252

philology, 16, 29, 214-227

physical, 81, 126, 128, 132, 138, 174, 260, 279, 282

physicalism, 131

physiological, 18, 70, 123-124, 166, 170, 304

physis, 198, 200

plants, 25, 91

Plato, 12, 35-49, 58, 89, 96, 137, 159, $164,198,247$

Platonic-Aristotelean-Kantian tradition, 48

Platonism, 26

pleasure, 287

Pletsch, C., 232, 270

pluralism, 15, 191, 194-195, 203-207

Poellner, P., 123-124, 126, 144

poetry, 12, 41, 128, 159, 257, 278

polemic reversal, 8,10

political, 43, 45-46, 49, 52, 151, 202, 204, 217, 232, 234, 236-240, 246, 254-258, 263, 281, 283, 291

Politycki, M., 215, 228
Porter, J. I., 17, 125, 144, 220, 228 , 276-285, 289

Pöschl, V., 224, 228

positivism, 14, 42, 46, 55-58, 104, $154,215,222,303$

power, 13-14, 25, 27, 29, 40-41, 6671, 84, 92-94, 98-110, 117, 123, 125-131, 151, 153, 160, 170, 179, 184, 186, 189, 191-192, 196, 200208, 225, 234-243, 256, 261, 264, 278

powerless, 187

pragmatic, 237

prayer, 27

predictability, 6, 49

prediction, 222

prehistory, 25, 89

prehuman, 179

presence in us, 104

pre-Socratic, 41, 46, 191

pride, 88, 103, 107, 109

priest, 58,90,979, 172, 1874, 250, 253

Priest, G., 10, 19, 90, 97, 140, 144,

$171,250,253$

primeval times, 94

primeval training to remember, 100 primitive, 12, 24-28, 35, 47, 88, 97

primordial, 13, 76-77, 99-100, 120, 249,283

primordial unity, 76, 283

principium individuationis, 16, 75, 248

prison, 40

prisoner, 175

processes, 11, 28, 75, 80-82, 92-96,

$103,108,126,128-131,142,205$

productivity, 16, 136, 238, 255

profanity, 239

progress, 52-53, 57, 64, 66, 70, 155,

$171,247,260$

progressus, 28

proletarian revolution, 236

promise, 53, 88, 97-98, 106, 108, 259,

262

properties, 2, 9, 81, 84

propositional, 40, 67, 128, 150, 177

protension, 7

proto-human, 102

proto-intentional, 14

protoplasm, 131 
protozoan, 126

providence, 155, 177-178, 180

psyche, 37

psychoanalysis, 73

psychological, 16, 37, 78, 89, 94, 129,

$149,159,173,221,223,225-226$,

231, 234, 247, 252-253, 291

psychologist, 66

psychology, 10, 39, 47, 66, 80, 95,

$149,159,167,278$

punishment, 25, 53, 89, 92, 95, 171,

186-187

purposeless, 76

purposive, 47

purposiveness, 93, 104

$Q$

quale, 11

qualitative, 11

quality, 222, 224-226, 256

quanta, 126-130

quantum, 117, 130uthors copy with perm quarks, 81

quasi-staticism, 9

quattrocento, 16, 235, 243-244, 248, 254, 257-258

Quine, W. V., 10, 135, 138, 144

$R$

radical becoming, 120, 128, 151

radicalism, 256

radicalization, 116-117

Ranke, L. von, 51, 261, 267, 270

ratiocination, 41

rational, 3-4, 6, 39, 41, 113, 151, 153,

159,305

rationalism, 38, 40, 49, 247

Rausch, 124

reactive, $13,52,72-73,95$

realism, 36, 45, 78, 122, 127, 132, 258

reality, 2, 4-5, 10-11, 36, 46, 54, 58,

81-82, 84-85, 113, 118, 120, 123,

$127,132,138,140,159,160,179$,

$189,223,278-279,305-306$

recitative, 292

recurring, 119, 181

redemption, 14 , 26, 28, 152, 175, 177-

281 reductionism, $65,73,222$

reductive, 10, 63-64, 132, 137, 151

Reformation, 91, 244, 249, 250-251, 259-260, 265, 268

Reformator des Lebens, 199

Reginster, B., 10, 19, 181, 190

regulative fiction, 8,10

regulative rule, 10

Rehm, W., 233-234, 239, 262, 270

Reibnitz, B. von, 245, 270

Reinhardt, V., 263, 270

relational, 126, 209

relations, $8,13-14,30,81,84,113-$ 114, 122-130, 138, 142, 154, 157, 191-192, 202, 209, 280

relativism, 135-136

religion, 92, 98-99, 102-103, 151, 238, 240, 251, 261, 279, 281, 283

religious, 25-27, 30, 40, 46, 52, 104, 150, 155-156, 196, 234-236, 260, 279, 281-282

religious ceremonies 2278

remedy, 6, 117-119

remember, 87-88, 96-102, 106, 182, 197

Renaissance, X, 16, 19, 30-32, 53, 91, 117, 174, 231-271, 286

Renan, E., 25-27, 33, 56

repetition, 149, 154-156, 180, 187, 189

replicative, 93-94

replicator, 70

republican, 17, 234, 236, 238, 240, 255

republics, 240

resentful, 90, 92

resentment, 57

resistance, 47, 64, 151, 207-209, 261

responsibility, 48, 95, 103, 108-109, 194, 234

Ressing, G., 241, 270

restlessness, 221

retension, 7

retrospective stance, $14,98-110$

revaluation, 52, 56-57, 59, 140, 150151,225

revenge, $27,88,98,153,181$

revolution, 52

revolutionary, 68, 184, 236, 256, 258 
rhetorical, 36, 44, 139, 158

rhetorician, 45

rhyme, 295

rhythm, 17, 292, 295-297, 301-307

Ribbeck, O., 217, 228

Richardson, IX, XI, 13, 19, 78, 85,

87-111, 125, 130-133, 143-144, 176,190

Richerson, P., 72, 74

rigidity, 137, 205, 207

Ritschl, F., 58, 213, 216-218, 220, 226, 228

Ritter-Santini, L., 262, 270

rituals, 25

Rockwell,W. T., 10, 11, 19

Roeck, B., 263, 266, 270

Rohde, E., 33, 214, 220, 228, 232

Roman, 221, 234, 244, 265

Romantic, 121, 128, 219, 234, 239, 244

Romanticism, 104

Ross, W., 241, 244t245, 247.0249, 264, 270

Rossi, R., 232, 270

Ruehl, X, XI, 16, 19, 231-272, 288

Ruhstaller, P., 232, 270

ruling caste, 257

Rumohr, C. F. von, 234-236, 238, 270

Rumsfeld, D., 41

Russian, 297

$S$

Sach-Philologie, 16, 215, 227

sacred, 158

sacrifice, 137,165

sacrilegious, 300

Sadie, S., 292, 296, 307

Salaquarda, J., 213-214, 228, 242, 244, 249, 265

Salin, E., 232, 245, 271

salvational, 14, 154-155

sameness, 136, 208

Sandys, J. E., 215-218, 228

Sautet, M., 256, 271

sceptic, 40, 78, 122

scepticism, 48, 77, 246, 264

Scheidekunst, 140

Schein, 3, 39, 137

Schieder, Th., 241, 271
Schiller, F. von, 135, 143, 196, 215, 234, 240, 259, 266, 284, 288

Schlechta, K., 232, 271

Schlegel, F. von, 121, 214

Schlegel, A. W. von, 214

Schmerzbringerin, 117-118

Schmidt, M., 254, 268, 271

scholastic factions, 16, 220

Schopenhauer, A., 2-3, 13-19, 40, 75, $77,79,82,89,115,121,124,155$, 160, 167-168, 171, 190, 192-204, 209-210, 225, 233, 241, 247, 248, 267-268, 271, 275-289

science, 4, 7, 10, 13, 17, 36, 42-43, 46-48, 52, 54, 59, 65, 72, 76, 78, $81,91,96,99,103,106,110,117-$ $118,220,238,246,264,275,282-$ $283,286,287$

scientism, 236, 260, 287

scriptural, 155

secularization, 240, 250-251, 264

secularized world-views 114

secularizers, 235

security, 236, 240, 261

sedimented layers of the past, 91

Sein, 4, 6, 28, 32, 122, 137, 197, 267

Sekurität, 236, 260

Selbstbewusstsein, 133

Selbstmord, 37

selected-designed, 95, 97

selection, 64, 67, 69-71, 93-94, 9699, 108, 131, 133, 141, 183, 213 selective, 16, 72, 77, 93, 97, 107, 109, $139,153,162,184,225,284$ self, 8, 17, 54, 99, 102, 106, 127, 131, $133,137-138,176,180,185,189$, $191,197,202,235,255,260,264$ self-knowledge, 91, 197

self-legislation, 15, 192-197, 200, 204, 207-209

self-reflection, 4, 100

semantic, 5, 129

semblance, 137,278

sensation, 92, 95, 201, 295

senses, 4-6, 26, 79, 85, 98, 117, 119,

$121,124,137,157-158,164$

sensorium, 115

sexual, 133

shame, 47, 201 
shamelessness, 219

sick, 89, 95, 108, 167, 170-171, 174, 259

sickness, 170, 177

Siemens, H. W., IX, XI, 15, 19, 191210, 215, 228

Simmel, G., 181, 190, 195, 210

Simonde de Sismondi, J.-Ch. L., 235, 271

simplicity, 24, 195

simplification, 131

simulation, 159

simultaneity, 10, 12, 114, 130, 133, 140,142

simultaneity-thinking, 113, 134, 140, 142

Sisyphus, 15, 163, 186-189

Sittengeschichte, 32

Sittengesetz, 195, 256

Sittlichkeit der Sitte, 97

Skinner, Q., 35, 45, 50, 277, 289

slave, 95, 108, 232, 251, 260-261.

slavish, 92, 206

Smith, J. H., 125, 144

sociability, 39

social, 14, 26, 43, 49, 64, 67, 73, 88,

93-109, 174, 208, 232, 235-237, 255

socialism, 260

socialists, 174

socialization, 89, 97

sociobiology, 68

sociology, 49

sociopolitical, 232, 236, 241, 253-254

Socrates, 13, 36, 38-42, 49, 79-80, 89, $135,150,163,167,286-287$

Socrates who makes music, 49

Socratic, 17, 38, 42, 45, 49, 243, 248, 282-283, 287

Soll, I., 181, 188, 190

Sommer, A. U., 250, 261-262, 271

Sophocles, 41-42, 45, 219, 286

sorrow, $88,90,187$

soul, 8, 27, 35, 104, 165, 171, 173,

197, 223, 225, 246, 264, 291, 302

soulless, 236

sovereign, 97, 202, 237

sovereignty, 103, 109, 253

spatiotemporal, 80 spectrum, 36, 134

Spencer, H., 13, 67-68, 72

Spengler, O., 30, 33

Spir, A., 79-80

spirit, 14, 29, 37, 44, 59, 149, 151, 215-216, 222, 226, 236, 240, 244, $250,252,263,287$

spiritual, 25, 30, 101, 104, 151-152,

$173,178,244,256$

spirituality, 295

Sprache, 229

Staat, 268, 281, 289

stability, 1, 29, 115, 126, 133-134

stable, 3, 7, 15, 135, 151, 283, 302

Stack, G. J., 115, 144

Stadelmann, R., 239, 271

Stahl, H.-P., 40, 43, 50

Stambaugh, J., 123, 144, 213, 228

Staten, H., 126, 144, 276, 289

static, 1, 6, 8, 15, 127, 137

staticism, 1-11

istaticist worldview, $2-6,8,11$

Stierle, K., 233, 271

Stilkunst, 265

stimulant, 207-208

stimulus, 207, 237

stoic, 117, 247

stomach, 304

Storr, A., 297, 307

Stravinsky, I. F., 297, 300

Strawson, G., 10-11, 18-19, 131-132, 143

strength, 7, 18, 65, 94, 141, 160, 164, 208, 224, 260, 295, 304

structuration, 38

structureless, 128

struggle, 42, 69-70, 73, 98, 154, 170, 191, 199-200, 204, 208, 214, 220, 225, 235, 238, 264, 281

Sturm und Drang, 233

style, 1, 44-45, 259, 261, 285

subconscious, 54, 185

subjection, 205-207

subjective, 77, 84, 127

subjectivism, 137

subjectivity, 84, 127, 233, 240, 262

sublime, 172, 256, 282-283

substance, 3, 8, 35, 84, 123, 127, 129

substantiality, 125 
substratum, 77, 84, 135

subterranean, 26

subtext, 261

suffering, 5-6, 70, 87-88, 95, 108, $118,137,150,159,164-175,180$ $183,247,256,279,282$

suicidal instincts, $15,169,182$

suicidal nihilism, 15, 153, 166, 169

suicide, 15, 25, 27, 153, 163-172, 181, 184,187

superhistorical, 31

superhuman, 15, 181, 183-186, 189, $257-258,278$

superman, 233, 262-263

superstitious, 25-26

suprahistorical, 103

suspicion, 27, 99, 208, 232

swimming and floating, 291-292

symbol, 26, 151, 173, 182, 187, 262

symbolic, 150, 160, 288

symmetrical, 208

symphonic, 202

symptom, 85,164

system, 4, 7, 67, 71, 121, 133, 237,

$254,282-283,285$

systematic, 3, 12, 48, 113, 121, 192,

276

$T$

taming, 7, 89, 170

tautology, 152

teleological, 14, 115, 130, 152, 154, 155

teleology, 55, 64, 92, 115, 121, 130

telos, 197

temperate zone, 53

temporal, $8,12,14,80,95,114,131$ -

132, 142, 152-156, 191-193, 200,

304, 306

temporal movement, 152-155

temporality, V, 3, 17, 114, 130-133,

$140,142,201$

tension, 9-13, 29, 91, 126, 138, 166,

$199,209,244$

testimony, 157

theatre, 38, 131

theatrical, 159

Theognideian, 215

theologian, 27, 31 theological, 48, 65, 156

theology, 84

theoretical, 10, 36-37, 81-82, 99-101, $103,109,177-179,188,192,199$, 213-214, 226, 237, 243, 246, 287

theory, 9, 14, 26, 28, 39, 43, 63, 66, 70-79, 82, 90, 100-102, 109, 111, $123,127,131-134,142,158,182$, $220,235,306$

therapy, 117

thing, 1, 3, 8, 28, 40, 44, 49, 53, 56, $67,77,83-87,115,126,127,168$, $172,197,254,284$

thing-in-itself, 3-4, 17, 54, 75, 77, 78, 81-84, 280, 283-284, 303-304

Thompson, E., 10, 19

Thucydidean, 12, 37, 41, 44-47

Thucydides, IX, 12, 18, 35-50, 58-59

tightrope, 173

time. See absolute time, adaptation over time, aporia of time,

atemporal, becoming gcircular time, conscious time, cyclic repetition, cyclical, diegetic time, eternal recurrence, eternal return, flux of time, historical time, ill-will towards time, infinite time, linear, non-circularity, novelistic model, permanent, pessimistic model, positivistic, power over time, reality of time, revenge against time and becoming, salvational, teleological, time for us, time itself, time signatures, time-atom theory.

time-atom theory, 7

time-in-itself, 18, 303-306

timeless, 7, 23, 142, 248

Todte, M., 240, 271

togetherness, 139

tonic, $18,292,304,307$

Tooby, J., 73

torture, 171,187

totality, 125, 133, 177

towardness, 93

Tracy, J. D., 244, 271

Traeger, J., 238, 271

tragedians, 243

tragedy, 12, 37, 45-47, 160, 219, 222, 226, 244, 247, 275-276, 286, 288 
tragic, 150, 152, 155-156, 159-160, 187, 219, 243, 250, 286, 287

tragic finitude, 152, 155

transcendence, 150-152, 155, 196, 197

transcendent, 85, 115, 125, 175, 198, 275,280

transcendental, 78-81, 110

transcendentally ideal, 77, 80-81, 85

transconsistent, 140

transformation, 6, 70, 155, 159, 199, 219,262

transgressive, 239, 256, 258, 263-264

transient, 137

transvaluation, 191, 209, 241-242, 250, 257, 259

transvaluative, 250, 259, 260, 262

trauma, 153, 155

Tristan, 292-301, 307

Troeltsch, E., 29-30, 33

trope, 157

tropical, 259

truth, 4-6, 9, 11, 36, 46, 48, 59, 77, 100-102, 104, 106-107, 110-111,

$114,116,119,122,124,131,142$,

$151,155,159,165-167,174,178$,

185, 194, 199, 221, 223, 247, 251, $275,279,281$

truthfulness, 39, 41, 48, 199, 249

Tugend, 242, 261

two-world metaphysics, 7, 121, 135

tyrannical, 203, 208, 237, 239-240,

255-256, 264

tyranny, 16, 78, 203, 207, 233, 255-

256, 295

$\ddot{U}$

überflüssig, 138

Übermensch, 135, 190

Uekermann, G., 262-263, 271

Ulfers, F., 215, 228

ultimates, 9

uncertainty, 6-7, 222, 256

unconscious, 11, 93, 129, 130-131, 133

undecidability, 158

undefinable, 28

unfreedom, 178, 208, 237

unhappiness, 281 unhealthy, 221, 305

unhistorical, 56, 103

unidirectional, 186

unification, 15

unified, 136, 186

unifying, 196, 202, 209

union, 139

uniqueness, 194

unitary, 26, 49

unity, 28, 76, 114-115, 121, 135, 136, 139, 142, 193, 202, 207, 287

universal, 48, 76, 92, 127, 191, 195, 204, 207-208, 254-255, 283, 287

universe, 48, 114, 131, 238

univocal, 157

unobservable, 81-82

unperceived posits, 82

Unschuld, 115

Unsinn, 6

unsinnlich, 6

unveiling, 174, 284

Usener, $\mathrm{H}_{\text {, }}, 23 \mathrm{2} 30,3308$

utilitarian, 239, 260

utility, 64, 66-68, 108

V

Vacano, D. A. von, 258, 271

vague, 9,305

value, 3-10, 13, 29, 32, 36, 42, 45, 53,

55, 63-68, 78, 96, 108, 110-115,

$119,121,132,139,150,154,163-$

$165,168,198,199,208,214,222$

227

value of life, 163-164, 198

Vattimo, G., 122, 144

vector, 129

veil, 84, 117, 238, 280, 283-284

veiled, 197, 254

vengeful, 250

Versteinerung, 300

vice, 97, 129, 195, 223, 257, 301

violence, 16, 208, 223, 233, 241, 261, 263,281

violent, 139, 141, 175, 231, 238, 240, 246,255

virtue, 3, 41-42, 78, 93, 96, 168, 173,

242, 261, 286, 295

visual, 305

vital, 116, 139, 259-260 
vitality, 235

Vivarelli, V., 247, 271

Vogt, E., 217, 228

Voigt, G., 240, 271

volition, 47, 129

Volpi, F., 242, 271

voluntary, 2, 15, 25, 27, 47

vornehm, 250

Vrba, E., 68, 73

W

Wagner, R., XIII, XIV, 15-17, 37, 144, 192-193, 199, 200-204, 218, $220,226,228,233,241-254,263-$ 271, 278-307

Wahn, 281-287

Waldenfels, B., 10, 19, 138, 144

war, 16, 41-46, 196, 202, 233, 245, $259,261,283$

warmth, 27

water, 9,100

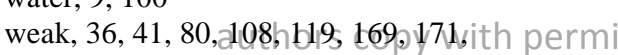
260

weakness, 36, 94, 135, 154, 260

Weber, M., 30, 33, 235, 237, 267, 272

Wechselbestimmung, 128

Weibel, O., 234, 272

Welshon, R., 118, 127, 129, 143-144

Wenzel, J., 236, 272

Werden, 6, 113, 121, 133, 144, 270.

See also becoming.

West, M. L., 30, 40, 50, 151

Wheeler III, S. C., 10, 19

whole, V, 1, 3, 8, 40, 43, 54, 56, 65,

$79,82,89-90,97,101,104,115$, $122,125,130-142,165,169,177$, 187, 193, 200, 216, 220-221, 225, 252, 278, 283-284, 296, 304

wholeness, 185

Widerfahrnis, 138

Wilamowitz-Moellendorff, U. von, 214, 216, 218, 220, 227-229

will to power, 14, 27, 64, 69-70, 72, $83,92,111-115,123-134,141-$ 142, 150-153, 167, 171, 184, 195, 257

Wille, 144, 289

Williams, B. IX, 12, 18, 33-50, 64, 66, 74,145 willing, 14-15, 79-80, 88, 90, 95, 100, 101-111, 118, 137, 154, 164, 176187

wills, 14, 91-94, 132, 167, 186, 284, 305

Winckelmann, J. J., 246

Wirklichkeit, 18

Wolf, F. A., 51, 213-216, 223, 226, 229

Wölfflin, H., 258, 272

world-disclosive, 14, 149, 160

world-negating, 3

worldview, 2, 118

worthlessness, 199, 225

Wort-Philologie, 16, 215

Wotan, 226

Y

Young, J., 123, 144, 168, 177-180, $187,190,269$

\section{Z Zsion by WdG 2008}

Zeeden, E. W., 239, 241, 272

Zeit, 199-200, 260, 264, 269, 272, 288

Zeitalter, 255

Zeitdauer, 300

Zuckert, C., 213, 229

Zugleich-Denken, 113, 134

Zukunft, 192

Zukunftsmusik, 296

Zukunftsphilologie, 214, 218 
authors copy with permission by WdG 2008 